\title{
Rejestry nieruchomości (księgi gruntowe) w dawnej Polsce - czy naprawdę istniały?
}

\section{O badaniach historycznoprawnych na tle artykułu Dariusza Felcenlobena Rejestry nieruchomości w dawnej Polsce*}

I. Stan badań nad prawem prywatnym dawnej Rzeczypospolitej jest daleki od ideału: w wielu przypadkach podstawowym opracowaniem pozostaje, nieco już leciwa, dwutomowa synteza Przemysława Dąbkowskiego ${ }^{1}$. Bodaj jej największą wadą jest oparcie się przede wszystkim na źródłach ówcześnie wydanych, co dla epoki staropolskiej powoduje brak szerszego uwzględnienia praktyki sądowej. Tym większe zainteresowanie wzbudził artykuł Dariusza Felcenlobena traktujący o rejestrach nieruchomości w dawnej Polsce. Autor - zajmujący się dotychczas geodezją i prawem geodezyjnym i od niedawna występujący na polu historii prawa ${ }^{2}$ - postawił sobie za zadanie - jak można dowiedzieć się w podsumowaniu - zwięzłe uwypuklenie ,typowych cech i funkcji, jakie pełniły one [księgi gruntowe - A. M.] na przestrzeni wieków w systemie prawnym państwa polskiego od czasów najdawniejszych do okresu pierwszego jego rozbioru" (s. 118). W kilkunastostronicowym szkicu zawarł uwagi dotyczące początków rejestrowania umów przeniesienia własności, korzeni i rozwoju instytucji ksiąg gruntowych w dawnym prawie polskim, $\mathrm{z}$ - zapewne zamierzonym ${ }^{3}$ - podziałem na okresy: średniowiecza i od XVI w. do rozbiorów. Omówił też niezmiernie istotną konstytucję $O$ waż-

* „Czasopismo Prawno-Historyczne” (dalej: CPH), t. LXV, 2013, z. 1, s. 105-120.

${ }^{1}$ P. Dąbkowski, Prawo prywatne polskie, t. I-II, Lwów 1910-1911.

${ }^{2}$ Wcześniej: D. Felcenloben, Przyczynek do historii powstania rejestrów gruntowych, CPH, t. LXIV, 2012, z. 1, s. 95-112.

${ }^{3}$ Wskazywać na to zdają się tytuły punktów w artykule: II. Księgi gruntowe jako systemowy element rzeczowego zabezpieczenia wierzytelności (s. 108) i IV. Księgi gruntowe i zasady ich prowadzenia w okresie od XVI wieku do czasu rozbiorów Polski (s. 113). Granicą czasową wydaje się przy tym połowa XVI w. - uwagi dotyczące unormowań prawa mazowieckiego z I połowy XVI w. znalazły się w punkcie II. 
ności zapisów z 1588 r., wraz z modyfikacją zasad zastawu bez dzierżenia (tzw. staropolskiej hipoteki) w wieku XVIII, oraz zarysował sposób rozgraniczania dóbr ziemskich. Nawiązujący do instytucji dzisiejszych rejestrów tytuł oraz prezentowany cel artykułu w szerszym sensie wpisuje się $\mathrm{w}$ trend coraz modniejszy w badaniach historycznoprawnych. Zakłada on ich swoiste podporządkowanie dyscyplinom dzisiejszego prawa w zakresie celu, przedmiotu, a - co za tym idzie - także metody ${ }^{4}$. W warstwie metodologicznej przekłada się to na korzystanie w pierwszym rzędzie z narzędzi właściwych prawoznawstwu, a zwłaszcza komparatystyki, z jednoczesnym uznaniem za drugorzędną metodologię nauk historycznych, opartą przede wszystkim na krytycznych badaniach źródłowych. Takie podejście do badań nad historią prawa przynosić może interesujące rezultaty - szczególnie ważne dla teorii prawa i prawa porównawczego - ale wymaga też znacznej dyscypliny badawczej i świadomości ryzyka popełnienia pewnych typowych błędów metodycznych ${ }^{5}$.

II. Jednym z podstawowych zagrożeń przy porównywaniu dzisiejszych i dawnych instytucji prawnych jest pułapka ahistoryczności. Wyraźna jest ona zwłaszcza w stosowanej terminologii, gdy teraźniejsze znaczenie czy wręcz funkcje rozwiązań prawnych przenoszone są na odległe czasy bez zachowania należytej ostrożności badawczej. Już na wstępie należy się zastanowić, czy nie wpada w nią całość omawianej pozycji. Jest to zadanie o tyle niełatwe, że D. Felcenloben unika zdefiniowania tematu badań, a stosowana terminologia daleka jest od konsekwencji. Zgodnie z tytułem, artykuł dotyczyć

${ }^{4}$ Zob. R. Zimmermann, Dziedzictwo Savigny'ego. Historia prawa, prawoznawstwo porównawcze $i$ ksztaltowanie się europejskiej nauki prawa, „Kwartalnik Prawa Prywatnego”, t. XIV, 2005, s. 1, s. 38-48. Trend ten można połączyć z metodą komparatystyczną w historii prawa, lub jak celnie ujął to Dirk Herbaut - stosowana historia prawa (applicative legal history), idem, Comparative law and Zimmermann's new ius commune: a life line or a death sentence for legal history? Some reflections on the use of legal history for comparative law and vice versa, [w:] Ex iusta causa traditum. Essays in honour of Eric H. Pool, red. R. ven den Bergh et al., Pretoria 2005, s. 146-147 (na s.136-153 szersze rozważania na temat sporu o model historii prawa), za: http://uir.unisa.ac.za/ bitstream/handle/10500/3492/Feesbundel\%20Heirbaut\%20D.pdf?sequence=1. Tomasz Giaro, prominentny przedstawiciel tej szkoły, rozważając rolę badań nad historią prawa, dobitnie stwierdził: „Również nauka historii jest częścią świata współczesnego, w związku z czym - jak każda inna nauka - musi odpowiadać na pytania współczesne. [...] Co więcej, nauka historii, która w żaden sposób nie chce lub nie umie przyczynić się do interpretacji problemów teraźniejszości, wydaje mijać się ze swym powołaniem", T. Giaro, Prawo i historia $w$ dobie globalizacji. Nowe rozdanie, [w:] Prawo w dobie globalizacji, red. T. Giaro, Warszawa 2011, s. 73.

${ }^{5}$ Zob. recenzje i uwagi z różnych perspektyw badawczych: P. Święcicka, Uwagi o metodzie badań historycznoprawnych. W zwiazku z rozprawa Jerzego Kolarzowskiego „Idea praw jednostki w pismach Braci Polskich. U narodzin nowożytnej koncepcji praw człowieka”, Wydawnictwa Uniwersytetu Warszawskiego, Warszawa 2009, CPH, t. LXIV, 2012, z. 1, s. 233-238; M. Ptaszyński, Jerzy Kolarzowski „Idea praw jednostki w pismach Braci Polskich. U narodzin nowożytnej koncepcji praw człowieka”, Wydawnictwa Uniwersytetu Warszawskiego, Warszawa 2009, „Odrodzenie i Reformacja w Polsce", t. LVI, 2012, s. 263-272. 
ma rejestrów nieruchomości $w$ dawnej Polsce, ale już w zacytowanym podsumowaniu wskazane są księgi gruntowe. $\mathrm{Z}$ różnych wzmianek zawartych w artykule wynika, że oba te terminy utożsamiane są ze sobą oraz z księgami grodzkimi i ziemskimi (s. 107-108). Na s. 110 autor wymiennie posługuje się terminami: rejestry gruntowe, rejestry nieruchomości i księgi gruntowe, a na s. 111 dodatkowo wprowadza pojęcie księgi wieczyste. W związku z tak dużym zamieszaniem terminologicznym należy zacząć od kwestii najbardziej ogólnej: czy dawne księgi sądowe można traktować w kategoriach dzisiejszego rejestru publicznego? Tomasz Stawecki, znawca problematyki rejestrów, zaproponował - wskazując jednocześnie na problemy z ustaleniem - szeroką definicję rejestru w ujęciu rekonstruktywistycznym. Według niej, modelowy rejestr winien spełniać następujące warunki: utworzenie zgodnie z przepisami obowiązującego prawa, prowadzenie przez organ o charakterze publicznym, rejestracja na podstawie decyzji, wywołanie skutków prawnych przez prowadzenie rejestru oraz jego jawnośćc ${ }^{6}$ Na pierwszy rzut oka dawne księgi sądowe spełniały powyższe warunki, przy bliższym spojrzeniu pojawiają się jednak pewne wątpliwości. Funkcjonowały one w odmiennych od dzisiejszych warunkach prawnych i kulturowych, stąd trudno mówić o precyzyjnych przepisach regulujących ich działanie. W większości przypadków normy dotyczące ksiąg były zwyczajowe, zresztą - mogły różnić się w zależności od regionu. Widać to choćby po stosowanej różnej terminologii we wpisach różnych czynności prawnych i procesowych ${ }^{7}$. Zmienne były formularze kancelaryjne samych czynności ${ }^{8}$. Nie istniała też wyraźnie określona ,procedura rejestracyjna": odbywała się ona ustnie, brak było pisemnych wniosków i postanowień o dokonaniu wpisu lub o odmowie (nota bene nie wypełnia to kolejnego z warunków definicji T. Staweckiego). Miarę dowolności postępowania stanowić może kwestia opłat kancelaryjnych za dokonanie wpisu. Nawet ten - newralgiczny z punktu widzenia podmiotów wnoszących o wpis do księgi - element w znacznej części pozostawał w sferze zwyczaju. Jeśli

${ }^{6}$ T. Stawecki, Rejestry publiczne. Funkcje instytucji, Warszawa 2005, s. 22-30.

${ }^{7}$ Problem różnorodności nazewnictwa wpisów do ksiąg sądowych grodu chełmskiego omówił Janusz Łosowski, Kancelaria grodzka chetmska od XV do XVIII wieku. Studium o urzędzie, dokumentacji, jej formach i roli w życiu spoleczeństwa staropolskiego, Lublin 2004, s. 167-177. Terminologia ta mogła być jeszcze zróżnicowana terytorialnie. Przykładowo: suspensio było w grodzie chełmskim używane na określenie wpisu odroczenia rozprawy ze względu na sąd; podczas gdy na Mazowszu w XVI/XVII w. stosowano ten termin na oznaczenie odroczenia rozprawy na żądanie stron, zob. AGAD, księgi ziemskie zakroczymskie wieczyste relacji, t. 88, passim. Częściej jednak stosowano w takim przypadku terminy: disiunctio, prorogatio, limitatio.

${ }^{8}$ Pewne wyobrażenie o tym zróżnicowaniu dają szczegółowe studia nad kancelarią Piastów mazowieckich, J. Grabowski, Kancelarie i dokumenty książat mazowieckich $w$ latach 1341-1381, Warszawa 1999. Zmienność formularzy potwierdza również - ostatnio badany - przykład kancelarii miejskiej w Knyszynie, Ł. Gołaszewski, Formacja zawodowa i praktyka sprawowania urzędu przez pisarzy miasta Knyszyna na początku XVIII wieku w świetle formularzy kancelaryjnych, „Miscellanea Historico-Iuridica", t. XII, 2013 (w druku). 
zaś regulowano go prawem stanowionym, to i tak normatywna wysokość tych opłat bywała nieprzestrzegana?

Kolejna wątpliwość związana jest z treścią ksiąg grodzkich. Według klasyfikacji zaproponowanej przez Janusza Łosowskiego, ich zawartość można podzielić na dłuższe wpisy (sądowe, majątkowo-finansowe, nieurzędowe) oraz krótkie adnotacje (urzędowe i nieurzędowe). W księgach zatem zamieszczano także różne informacje nieurzędowe, mające niewiele wspólnego z dzisiejszymi rejestrami. Była to na przykład twórczość kancelistów (,literatura palestrancka”) o charakterze ludycznym i literackim. Można znaleźć tam żartobliwe wpisy dotyczące zmyślonych czynności prawnych, krótkie epigramaty i maksymy o charakterze religijno-filozoficznym, satyrycznym, czy nawet - erotycznym ${ }^{10}$.

Obiekcje wobec traktowania ksiąg jako rejestru wzbudza zakres uprawnień i obowiązków organu dokonującego wpisu do księgi (pisarze ziemscy i grodzcy, a w miarę upływu czasu personel kancelarii: regenci i susceptanci). Wprawdzie mógł on odmówić zamieszczenia wpisu w księgach, lecz nie miał uprawnień do ingerencji w samą treść dokumentu. Dowodzi tego fragment roty przysięgi pisarza ziemskiego, w której znalazły się jego podstawowe obowiązki: „wiernie stron zeznawania, kontrowersje, żądania, albo oświadczenia prawne, albo sędziego skazania, w księgi Ziemskie będę wpisował; i będę się starał, aby były wpisowane"11. Zgodnie z dzisiejszą klasyfikacją prawoznawczą rola organu prowadzącego księgi w większym stopniu odpowiada ewidencji niż rejestrowi ${ }^{12}$.

Przytoczone wyżej zastrzeżenia dowodzą, że dawne księgi sądowe nie do końca wpisują się w modelową definicję rejestru. Można je w najlepszym

${ }^{9}$ Szerzej o wysokości opłat i praktyce ich pobierania: J. Łosowski, Kancelaria grodzka ..., s. 143-145; A. Moniuszko, Mazowieckie sady ziemskie (1588-1648). Organizacja - funkcjonowanie - postępowanie, Warszawa 2013, s. 150-156. Precyzyjniejsze, partykularne regulacje zaczęły pojawiać się pod koniec XVII w. i w wieku XVIII, kiedy to poszczególne kancelarie publikowały taksy opłat, zob. np. P. Dąbkowski, Dwie taksy kancelaryjne sq̨du halickiego z XVII i XVIII wieku, Lwów 1903, s. 6-8; Archiwum Komisyi Prawniczej, t. VIII, cz. 2, wyd. S. Kutrzeba, Kraków 1909, s. 185-189 (Wykaz taks pobieranych przez kancelarye grodzka krakowska, potwierdzonych przez starostę krakowskiego F. Wielopolskiego); J. Bielecka, Kancelaria grodzka wielkopolska w XVI-XVIII w., „Studia Źródłoznawcze”, t. 1, 1957, s. 142 (Aneks 8. Instrukcja Franciszka Leszczyc Dobrzyckiego, pisarza grodzkiego kaliskiego dla susceptantów tego grodu wraz z tabela opłat sq̨dowych, Kalisz 11 VIII 1739).

${ }^{10}$ Przykłady: P. Dąbkowski, Palestra i księgi sądowe ziemskie i grodzkie w dawnej Polsce, „Pamiętnik Historyczno-Prawny”, t. III, 1926, z. 2, s. 104-105; J. Bielecka, Kancelaria grodzka..., s. 129; J. Łosowski, Kancelaria grodzka ..., s. 177-179 (tamże na s. 165-179 omówienie klasyfikacji i treści zawartości akt grodzkich na przykładzie ksiąg grodzkich chełmskich).

${ }^{11}$ Tekst roty za: S. Sarnicki, Statuta y metrika przywileiow koronnych, Kraków 1594, s. 561; J. Januszowski, Statuta, prawa i constitucie koronne lacińskie i polskie ze Statutów, Łaskiego, Herborta i z constitucyi Koronnych zebrane, Kraków 1600.., s. 496-497. Podobnie podpisek przysięgły (vicenotarius iuratus)/regent zobowiązywał się do bezstronnego przyjmowania wpisów i wiernego ich przepisywania. Przykładowo: przysięga podpiska wyszogrodzkiego Michała Falęckiego z 1637 r., AGAD, księgi ziemskie wieczyste relacje wyszogrodzkie, t. 14, k. 324-324v.; regenta sądeckiego Jana Stadnickiego z 1682 r., Archiwum Komisyi..., s. 168. O obowiązkach pisarza i regenta, zob. P. Dąbkowski, Palestra i księgi sądowe ziemskie..., s. 102, 104.

${ }^{12}$ T. Stawecki, Rejestry publiczne..., s. 22. 
wypadku traktować - nawiązując ponownie do koncepcji T. Staweckiego jako przypadek graniczny. W takim razie należy jednak bardzo precyzyjnie określić, na czym polegają różnice pojęciowe. Nasuwają się jednak poważne wątpliwości, czy w ogóle warto to robić. Odmienności są bowiem znaczne, a jednocześnie w szeroko pojętych naukach historycznych (historia, archiwistyka, dyplomatyka, historia prawa) utrwalone jest pojęcie ksiag sqadowych. Dodatkowym utrudnieniem w swobodnym operowaniu terminem rejestr w stosunku do dawnych ksiąg jest jego historyczne znaczenie. Nazwa regestr, rejestr funkcjonowała $\mathrm{w}$ staropolskim języku prawnym i prawniczym, pokrywając się z dzisiejszym znaczeniem spisu lub wykazu. Na gruncie prawa procesowego oznaczał on spis spraw napływających do sądu, według którego ustalano kolejność ich rozpoznawania. Od XVIII w. powyższe spisy, prowadzone już w formie odrębnej księgi, zaczęto nazywać wokandami i termin ten do dziś pozostał w użyciu ${ }^{13}$. Funkcjonowało zresztą wiele regestrów dla poszczególnych kategorii spraw, tworząc skomplikowaną mozaikę, w której odpowiednie poruszanie się było jedną z podstawowych umiejętności ówczesnych zawodowych prawników ${ }^{14}$. Rejestry (łanowe, podymne, pogłówne) tworzono dla celów fiskalnych: stanowiły one terytorialne wykazy obciążeń podatkowych ${ }^{15}$. Pojęciem tym posługiwano się również na oznaczenie różnego rodzaju spisów, w tym także ksiąg lub wpisów do nich ${ }^{16}$. W efekcie był to

${ }^{13}$ O. Balzer, Przewód sądowy polski, wyd. W. Hejnosz, Lwów 1935, s. 87-88; J. Rafacz, Dawny proces polski, Warszawa 1925, s. 37-38; S. Kutrzeba, Dawne polskie prawo sadowe w zarysie, Lwów-Warszawa-Kraków 1927 (wyd. 2), s. 86-87.

${ }^{14}$ Szerzej o systemie regestrów w Trybunale Koronnym i różnych nadużyciach związanych z ich stosowaniem: W. Bednaruk, Trybunat Koronny. Szlachecki sąd najwyższy w latach 1578-1794, Lublin 2008, s. 142-156 (zob. też uwagi w: P. Gawron, A. Moniuszko, O Trybunale Koronnym w czasach Wazów. Uwagi na marginesie pracy Waldemara Bednaruka ,,Trybunat Koronny. Szlachecki sąd najwyższy w latach 1578-1794”, CPH, t. XLII, 2010, z. 1, s. 416-417).

${ }^{15}$ Przykładowe, wydane koronne rejestry poborowe: Źródła dziejowe, t. XII-XXVI: Polska XVI w. pod względem geograficzno-statystycznym, t. I-II: Wielkopolska, wyd. A. Pawiński, Warszawa 1883; t. III-IV: Małopolska, wyd. A. Pawiński, Warszawa 1886; t. V: Mazowsze, wyd. A. Pawiński, Warszawa 1895; t. VI: Podlasie, cz. 1, wyd. A. Jabłonowski, Warszawa 1908; t. VII: Ziemie ruskie. Ruś Czerwona, cz. 1, wyd. A. Jabłonowski, Warszawa 1902; t. VIII: Ziemie ruskie. Wołyń i Podole, wyd. A. Jabłonowski, Warszawa 1889; t. IX: Ziemie ruskie. Ukraina, wyd. A. Jabłonowski, Warszawa 1894; t. XII: Prusy Królewskie, cz. 1, wyd. I. T. Baranowski, Warszawa 1911; Rejestr pogłównego ziemi przemyskiej z 1674 roku, wyd. Z. Budzyński, K. Przyboś, Przemyśl 2000; wydane rejestry litewskie: Metryka Litewska. Rejestry podymnego Wielkiego Księstwa Litewskiego: województwo brzeskie litewskie 1667-1690, oprac. A. Rachuba, Warszawa 2000; Metryka Litewska. Rejestry podymnego Wielkiego Księstwa Litewskiego: województwo nowogródzkie 1690, oprac. A. Rachuba, H. Lulewicz, Warszawa 2002; Metryka Litewska. Rejestry podymnego Wielkiego Księstwa Litewskiego: województwo mścisławskie 1667, oprac. A. Rachuba, Warszawa 2008; Metryka Litewska. Rejestry podymnego Wielkiego Księstwa Litewskiego: województwo smoleńskie 1650, oprac. S. Dumin, A. Rachuba, Warszawa 2009.

${ }^{16}$ Przykładowo: rejestr ksiąg grodzkich od 1432 r. zamieszczony w 1655 r. w księdze grodzkiej wschowskiej, zob. J. Bielecka, Kancelaria grodzka ..., s. 121; Regestr ksiag dawnych województwa krakowskiego oblatowany w księdze ziemskiej krakowskiej z 1792 r., Archiwum Komisyi..., s. 281-292. 
termin znaczeniowo różniący się od księgi, a w części przypadków podrzędny w stosunku do niej: w jednej księdze sądowej mogły być zamieszczone różne regestry. Historyczne różnice w znaczeniu słowa rejestr podkreślał $\mathrm{T}$. Stawecki, sceptycznie zresztą podchodząc do możliwości prostego łączenia ze sobą dawnych ksiąg sądowych z dzisiejszymi rejestrami ${ }^{17}$.

O ile można mieć poważne zastrzeżenia do używania pojęcia rejestr publiczny do dawnych ksiąg sądowych, to proponowane w omawianym artykule stosowanie terminu rejestr nieruchomości jest zupełnie bezzasadne. Utożsamianie go z księgami gruntowymi, wzmianki o: „księgach gruntowych jako systemowym elemencie zabezpieczenia wierzytelności” (s. 108), „właściwości miejscowej urzędu rejestrowego" (s. 111), „księgach urządzanych dla danej nieruchomości” (s. 116) świadczą o tym, iż D. Felcenloben przyjął istnienie w prawie koronnym w okresie XIV-XVIII w. rozwiązań wprowadzonych na ziemiach polskich na przełomie XVIII i XIX w. Jest to nieporozumieniem oczywistym dla każdego, kto miał bliższą styczność z księgami ziemskimi i grodzkimi. Jedną z głównych wad tzw. hipoteki staropolskiej stanowił przecież brak wyodrębnienia wpisów dotyczących praw rzeczowych z pozostałych umów ${ }^{18}$ - jeśli mówimy o stanie po utworzeniu w ramach prowadzonych ksiąg serii inskrypcji - albo nawet ze wszystkich wpisów w czasach przed powstaniem podziału ksiąg na serie ${ }^{19}$. System osobnych ksiąg, prowadzonych w celu rejestrowania zmian w stanie prawnym poszczególnych nieruchomości i oparty na zasadzie wpisu, pojawił się dopiero po upadku Rzeczypospolitej. Skoro zatem nie wyodrębniono w żaden sposób zbioru wpisów dotyczących nieruchomości, to trudno zgodzić się koncepcją istnienia rejestrów nieruchomości w średniowieczu i epoce Rzeczypospolitej szlacheckiej. Nota bene, symptomatyczna jest konstatacja autora, który z zaciekawieniem odkrywa, że $\mathrm{w}$ tzw. rejestrach pojawiają się też wpisy z wyrokami rozgraniczającymi nieruchomości czy też ustanawiające ograniczone prawa rzeczowe (s. 107). Jest to kolejna kwestia oczywista dla osób pracujących ze szlacheckimi księgami sądowymi. Można nawet dodać, choć trąci to komunałem, że różnorodność pojawiających się w nich wpisów jest zdecydowanie większa.

Należy podnieść jeszcze jedno zastrzeżenie związane z błędem ahistoryczności: brak precyzyjnego umiejscowienia opisywanych instytucji w cza-

${ }^{17}$ T. Stawecki, Rejestry publiczne..., s. 21.

18 Janina Bielecka, bazując na materiale wielkopolskim, zwróciła uwagę na to, że najczęstsze wpisy w serii inskrypcji dotyczyły umów pożyczek bez zabezpieczenia zastawem na nieruchomościach, eadem, Organizacja $i$ działalność kancelarii ziemskich $i$ grodzkich wielkopolskich XIV-XVIII w., „Archeion”, t. 22, 1954, s. 131-132.

${ }^{19}$ Podział ksiąg grodzkich i ziemskich na serie akt nastąpił stosunkowo późno - przeważnie zaczęto go wprowadzać w II połowie XVI w., zob. J. Łosowski, Kancelaria grodzka..., s. 181-186 (w tym tabela 14 Chronologia powstawania głównych serii aktowych w polskich kancelariach grodzkich na s. 182); Z. Wojas, Kancelaria grodzka krakowska za starosty Jana Firleja w latach 1572-1574, „Archeion”, t. 27, 1957, s. 196-198; J. Bielecka, Organizacja i działalność..., s. 132-133, 138. 
sie i przestrzeni. Jest to istotne ze względu na istnienie partykularnych systemów prawa ziemskiego. Przy korzystaniu z prawa mazowieckiego wypada zaznaczyć, że zostało ono zniesione w 1577 r., a jedynie niewielka część jego norm przetrwała w postaci Eksceptów mazowieckich. D. Felcenloben w swoim artykule często sięga do regulacji mazowieckich, nie wspominając o tej kwestii, nie zawsze nawet wskazując, że chodzi o prawo stanowione tylko dla tego regionu. Zdaje się przy tym ekstrapolować rozwiązania mazowieckie na całość prawa koronnego. Przykładowo: na s. 109 umieszczono wymieszane normy mazowieckie i koronne, bez stosownego ich rozróżnienia. Gdy więc czytamy o statucie z roku 1496, można mieć wątpliwości, czy autorowi chodzi o konstytucje sejmu z tego roku (zwane w artykule Statutem piotrkowskim), czy też o statuty książąt mazowieckich ${ }^{20}$. Przedstawiona za Karolem Duninem typologia zastawów (prosty i pod przepadkiem) zupełnie pomija zastaw do wydzierżenia (ekstenuację). Badania Stanisława Russockiego udowodniły, że rzeczywiście nie stosowano go na Mazowszu ${ }^{21}$, lecz przecież występował on w prawie koronnym - m.in. stanowił jeden z ważniejszych aspektów reform skarbu królewskiego w I połowie XVI w. ${ }^{22}$ Podobne zastrzeżenie można podnieść w stosunku do uznania - znowuż za K. Duninem ${ }^{23}$ - zastawu na upad (sub lapso) za forme sprzedaży nieruchomości z prawem odkupu (s. 108). Uzasadnione jest to dla prawa mazowieckiego, m.in. przez zasadę liczenia 3-letniego terminu na wykonanie prawa retraktu przez krewnych od momentu intromisji w zastawione dobra, nie zaś

${ }^{20} \mathrm{~W}$ tym przypadku chodziło o statut Konrada III. Na marginesie można zauważyć, że wątpliwy jest podany rok 1496 jako data regulacji ustanawiającej sposób określenia stosunku między wysokością zobowiązania a ilością zastawianej ziemi (s. 108). Normę tę ze statutem Konrada III z 1496 r. powiązał Jan Wincenty Bandtkie-Stężyński, Jus Polonucum: codicibus veteribus manuscriptum et editionibus quibusque collatis, wyd. J.W. Bandtkie-Stężyński, Warszawa 1831, s. 451, a źródło to wykorzystał w swej pracy K. Dunin, Dawne mazowieckie prawo, Warszawa 1880, s. 175. Zapewne na tych przesłankach oparł się autor, choć to przypuszczenie, gdyż w tekście nie ma odesłania ani do źródła, ani do literatury. Tymczasem - pochodzący prawdopodobnie z początków XVI w. - wydany przez Oswalda Balzera tzw. rękopis petersburski statutów mazowieckich nie zawiera artykułu De intromissione debito, Archiwum Komisyi Prawniczej, t. V, wyd. O. Balzer, Kraków 1897, s. 231, 292-294. Jakub Sawicki na tej podstawie wykazywał, iż w oryginale statut miał węższy zakres, a kilka artykułów - w tym dotyczący wwiązania w dobra z tytułu niespłaconego zobowiązania - pojawiło się w wersji znanej ze Zwodu Prażmowskiego z 1531 r.; Iura Masoviae Terrestria, wyd. J. Sawicki, t. II, Warszawa 1973, s. 67.

${ }^{21}$ S. Russocki, Formy władania ziemia w prawie ziemskim Mazowsza (koniec XIV - połowa XVI wieku), Warszawa 1961, s. 262.

${ }^{22}$ A. Sucheni-Grabowska, Odbudowa domeny królewskiej w Polsce 1504-1548, Wrocław-Warszawa-Kraków 1967, s. 47-52, 60-111. Zygfryd Rymaszewski i Jacek Matuszewski stwierdzili jego stosowanie - acz stosunkowo rzadkie - w badanej przez siebie praktyce wieku XV, Z. Rymaszewski, Zastaw w świetle praktyki sądów małopolskich, „Zeszyty Naukowe Uniwersytetu Łódzkiego”, seria I, z. 26, 1962, s. 121; J.S. Matuszewski, Zastaw nieruchomości w polskim prawie ziemskim do końca XV stulecia, „Acta Universitatis Lodzensis. Folia Iuridica”, seria I, z. 53, Łódź 1979, s. 19-28.

${ }^{23}$ K. Dunin, op. cit., s. 179. 
- przeniesienia własności ${ }^{24}$. Czy jednak należy przenosić tę normę na prawo koronne? Pogląd o zastawie - alienacji w prawie koronnym raczej odnosi się do zastawu użytkowego. Poza tym formułowany jest on nieco ostrożniej - mówi się o zbliżeniu do alienacji, zacieraniu różnic między zastawem a alienacją ${ }^{25}$. Kolejnym przykładem zamieszania wywołanego brakiem rozróżniania poszczególnych systemów prawa dawnej Rzeczypospolitej mogą być uwagi dotyczące przedawnienia praw do nieruchomości w przypadku niedokonania intromisji (s. 107). W dwóch stojących obok siebie zdaniach (wersy 2-7) padają dwa, sprzeczne ze sobą, terminy przedawnienia: 3-letni i 10-letni. Zagadkę rozwikłać można po sięgnięciu do pracy P. Dąbkowskiego, do której zresztą odesłano w artykule. Wyraźnie wskazano w niej, że termin 3-letni występował w prawie mazowieckim, zaś 10-letni w II Statucie litewskim $^{26}$. D. Felcenloben uznał widać tę informację za mało istotną, nie odnosząc się też do tego, czy podobne rozwiązanie w ogóle funkcjonowało w Królestwie Polskim. Bezrefleksyjne łączenie prawa koronnego i mazowieckiego prowadzi do wręcz kuriozalnych stwierdzeń, z których wynika, iż w XV w. w Królestwie Polskim panowali książęta... ${ }^{27}$

Przy syntetycznym opisie instytucji prawnej i jej przemian na przestrzeni kilku wieków, dla zachowania jasności przekazu istotna jest precyzja w operowaniu czasem. Brakuje jej w omawianym artykule, który nie ma konsekwentnego układu (przyjęty można chyba określić jako rzeczowo-chronologiczny). Problemy widoczne są zwłaszcza przy wywodzie odnoszącym się do średniowiecza. Na s. 109-110 po opisie mazowieckich (czego, jak już wspomniano, nie zasygnalizowano) regulacji dotyczących zastawu z XV i XVI w., przytoczono normy ze Statutów Kazimierza Wielkiego, by następnie przejść do wcześniejszych - pochodzących z przełomu XIII i XIV w. - przykładów stosowania zabezpieczenia w postaci zastawu bez dzierżenia. Nieco razi też stosowanie terminów niedookreślonych, takich jak: „wówczas” (s. 107), „z upły-

${ }^{24}$ Art. 88 II Zwodu prawa mazowieckiego (tzw. Zwód Goryńskiego), Iura Masoviae ..., t. III, Warszawa 1974, s. 168-169.

${ }^{25}$ Historia państwa i prawa polskiego, red. J. Bardach, t. I, Warszawa 1965 (wyd. 2), s. 503; Z. Rymaszewski, Zastaw..., s. 119-120. O zastawie - alienacji nie wspomina jednak J.S. Matuszewski w pracy opartej na małopolskiej, wielkopolskiej i ruskiej praktyce sądowej, idem, op. cit., passim.

${ }^{26}$ P. Dąbkowski, Prawo prywatne..., t. II, s. 198-199.

${ }^{27}$ Przykład pierwszy: „W okresie XIV-XV w. umowy przeniesienia praw do posiadłości zawierane były także bezpośrednio przed sądami, ale i wówczas czynność alienacji wymagała potwierdzenia przez księcia" (s. 105-106). W tekście autor opisuje przy tym średniowieczna Polskę (s. 105), a zdanie powyższe niemal dosłownie zaczerpnął z pracy K. Dunina o średniowiecznym prawie mazowieckim. Jednak tego, że akurat opisywane są rozwiązania mazowieckie można się domyślać tylko z podanego w przypisie tytułu cytowanego dzieła. Przykład drugi: „kancelarie rejestrowe książąt (Metryka Koronna lub Metryka Mazowiecka)" (s. 107). Metrykę Koronną prowadzono zapewne od końca XIV w. (najstarsze zachowane wpisy pochodzą z połowy XV w.) do XVIII w., trudno ją zatem uznać za kancelarię książęcą. 
wem czasu” (s. 108), „w początkowym okresie” (s. 108) bez bezpośredniego połączenia ich z czasem.

Z kolei przykład fragmentarycznego ujęcia stanowi opisywany w punkcie III (s. 112-113) sposób wyznaczania granic. Autor zaznacza, że opis dotyczy średniowiecznej Polski, bez tłumaczenia, dlaczego nie podjął się krótkiej charakterystyki czasów późniejszych. Podane przykłady pochodzą z wieku XIII, tymczasem nie dowiadujemy się niczego o funkcjach podkomorzego i komorników ziemskich oraz postępowaniu przed sądami podkomorskimi, które powstały zapewne na przełomie XIV i XV w. - zatem jeszcze w opisywanym okresie ${ }^{28}$. Jest to o tyle dziwne, że w przypisach 5 i 35 przywołano pracę Stosława Łaguny, w której łatwo można znaleźć stosowne ustępy ${ }^{29}$.

III. Podstawę źródłową omawianego artykułu - zresztą nader oszczędnie wykorzystywaną - tworzą normy prawa stanowionego (statuty królów polskich i książąt mazowieckich, konstytucje sejmowe). Można przy tym odnieść wrażenie, że nawet te podstawowe źródła niekiedy bywają cytowane z drugiej ręki, czego nota bene nie zaznaczono. Na s. 111 zacytowano konstytucję z 1496 r., odwołując się do tekstu tomu I Volumina legum: wszelkie inskrypcje ujawnione $w$ księgach grodzkich, w przeciagu jednego roku do wlaściwych miejscowo ksiag ziemskich winny być przeniesione (przyp. 29) ${ }^{30}$. Problem

${ }^{28}$ Najwcześniej - bo na pewno już w I połowie XV w. - sądy podkomorskie wyodrębniły się z sądów ziemskich w Małopolsce, S. Kutrzeba, Sądy ziemskie i grodzkie w wiekach średnich, „Rozprawy Akademii Umiejętności. Wydział Historyczno-Filozoficzny”, t. XL-XLII, Kraków 1901-1902, I. Województwo krakowskie, s. 50; II. Województwo sandomierskie, s. 23; L. Białkowski, Lubelska księga podkomorska piętnastego wieku, Lublin 1934, s. VIII. W Wielkopolsce proces ten nastąpił na przełomie XV i XVI w., A. Gąsiorowski, Urzędnicy zarządu lokalnego w późnośredniowiecznej Wielkopolsce, Poznańskie Towarzystwo Przyjaciół Nauk. Wydział Historii i Nauk Społecznych. Prace Komisji Historycznej, t. XXIV, z. 3, Poznań 1970, s. 45-38. Na Podlasiu sąd podkomorski powstał zapewne w początkach XVI w. (pierwsza wzmiankowana bielska księga podkomorska zaczyna się od 1519 r.), J. Soszyński, Księgi podkomorskie bielskie wg spisu z 1648 r. Przyczynek do badań nad staropolska kultura prawnicza, „Miscellanea Historico-Archivistica”, t. XI, 2000, s. 94; w Wielkim Księstwie Litewskim po reformie sądownictwa z 1564 r. - choć już wcześniej można zaobserwować jego początki, zob. A. B. Zakrzewski, Wielkie Księstwo Litewskie (XVI-XVIII w.). Prawo - ustrój - społeczeństwo, Warszawa 2013, s. 187 (tamże literatura). Najpóźniej - na przełomie XVI i XVII w. - sądy podkomorskie w pełni wyodrębniły się w województwie mazowieckim, A. Moniuszko, op. cit., s. 26-28.

${ }^{29}$ S. Łaguna, O prawie granicznem polskiem, [w:] Pisma Stosława Laguny, wyd. J. Bieliński, Warszawa 1915, s. 94-102 ( w artykule wykorzystano wydanie z 1858 r.).

${ }^{30} \mathrm{Na}$ marginesie można zauważyć rozbieżności w opisie bibliograficznym Volumina legum. Stosowany jest wszędzie skrót $\mathrm{Vol}$. leg., natomiast później w krótkim artykule występują różne formy opisu bibliograficznego: numer tomu (cyfra rzymska) i strona (przypisy: 29, 47, 53); numer tomu (cyfra arabska) i strona (przyp. 57); numer tomu (cyfra rzymska), strona, pozycja (sic!) (przypisy: 49, 50, 59, 60); oraz numer tomu (cyfra rzymska), strona, pozycja i artykuł (sic!) (przyp. 39). Dwa ostatnie systemy oznaczania stanowią świadectwo braku rozeznania autora na historycznym polu badawczym: potraktował on systematykę Volumina legum tak jak dzisiejszych publikatorów aktów prawnych. Oczywiście domniemana pozycja jest niczym innym jak foliacją z pierwszego wydania pijarskiego, zachowaną na marginesach w wydaniu Jozafata Ohryzki (tym zapewne posłu- 
w tym, że tekst konstytucji jest łaciński, natomiast cytat w języku polskim. Kto dokonał przekładu - nie wskazano. Jest on jednak niepokojąco zbieżny z fragmentem zdania, pojawiającym się w pracy Ksawerego Józefowicza o hipotece w Królestwie Polskim (zob. punkt V) ${ }^{31}$. Na s. 109 pojawia się wzmianka o „przyjętym zwyczaju” w zakresie terminów wykupu zastawionych dóbr, zależnych od regionu Mazowsza. D. Felcenloben powołuje się przy tym na statuty Ziemowita IV z lat 1387-1390 wydane w Starodawnych prawa polskiego pomnikach (przypisy 18-19), w obu przypadkach błędnie. Wynika to z niezbyt szczęśliwego skrótu z pracy K. Dunina i zawartego w niej aparatu naukowego. Wspominając o 3-letnim terminie wykupu (zresztą odnoszącym się do retraktu - zob. punkt IV), odwołał się on do statutu z 1390 r. (Janusza I), wydanego w Jus Polonicum przez J.W. Bandtkie-Stężyńskiego, stosując w przypisie skrót: Stat. 1390. Venditio etc. (Jus. Pol. 423) ${ }^{32}$. Natomiast dla terminu wynoszącego rok i 6 tygodni przywołał statut wydany dla księstwa płockiego przez Ziemowita IV z 1387 r., zamieszczony w wydanych przez Antoniego Zygmunta Helcla Starodawnych prawa polskiego pomnikach, stosując skrót: Helcel I, 276. II ${ }^{33}$. D. Felcenloben, zdaje się - nie zrozumiawszy stosowanego przez Dunina systemu skrótów, w przypisie wskazał, iż oba statuty zamieszczono w wydaniu Helcla, przy czym chyba uznał, że II umieszczone w przypisie Dunina oznacza II tom (tymczasem chodzi tu o II artykuł statutu). Autor sięgnął też do tego źródła i znalazł w nim statut Ziemowita IV z 1390 r. Zapewne w ten sposób należy zrekonstruować sposób powstania błędnej - by nie rzec: kuriozalnej - treści przypisów 18 i 19, odsyłających do tomu I wydania Helcla dla statutu z 1390 r., oraz tomu II dla statutu z 1387 r. (s. 109). W rzeczywistości statut księcia płockiego Ziemowita IV z 1387 r. znajduje się w tomie I, natomiast wskazywany statut tegoż władcy z 12 III 1390 r. dotyczy posiadania ziemi (regulacje dotyczące wątpliwości w zakresie sołectw, osadnictwa chłopów i prawa rycerskiego), nie zaś wykupu dóbr ${ }^{34}$. To ostatnie zagadnienie znalazło się natomiast w statucie z 20 III 1390 r., tyle że

żono się w omawianym artykule). Natomiast uznanie, że konstytucja $O$ ważności zapisów z $1588 \mathrm{r}$. jest artykułem 28 oraz wzmianka o konstytucji zawierającej ustawe „o ważności zapisów” (s. 114) budzą niejakie zaniepokojenie: czyżby D. Felcenloben uznawał, iż całość dorobku ustawodawczego sejmu koronnego z 1588 r. nazywać należy konstytucją, składającą się z poszczególnych ustaw lub artykułów? Na temat konstytucji oraz - szerzej- uchwał sejmowych w tym okresie zob. I. Lewandowska-Malec, Sejm walny koronny Rzeczypospolitej Obojga Narodów i jego dorobek ustawodawczy (1587-1632), Kraków 2009, s. 239-256 (tamże dalsza literatura).

${ }^{31}$ K. Józefowicz, Przepisy o hipotekach, czyli wyktad prawa hipotecznego w Królestwie Polskiem obowiąującego, Warszawa 1873, s. 6. Należy przy tym zaznaczyć, iż nie jest to przekład treści konstytucji z 1496 r., lecz jej dość swobodna parafraza.

${ }^{32}$ K. Dunin, op. cit., s. 157, przyp. 6; statut Janusza I, zob. Jus Polonicom ..., s. 423-424; Iura Masoviae..., t. I, s. 59, poz. 39.

${ }^{33}$ K. Dunin, op. cit., s. 157, przyp. 7; stosowny statut: Starodawne prawa polskiego pomniki, t. I, wyd. A.Z. Helcel, Warszawa 1856, s. 275-276, por. Iura Masoviae..., s. 50, poz. 34.

${ }^{34}$ Starodawne prawa..., s. 277; Iura Masoviae..., s. 56-57, poz. 38. 
wydanym przez księcia czerskiego Janusza I. Dwa wskazane przykłady wiele mówią o sposobie wykorzystywania źródeł w omawianym artykule.

Należy też zauważyć, że przytaczane - w ten czy inny sposób - źródła pochodzą z wydawnictw XIX-wiecznych, podczas gdy dostępne są nowocześniejsze ich edycje. Powyższą uwagę można przede wszystkim odnieść do prawa mazowieckiego, cytowanego ze Starodawnych prawa polskiego pomników, podczas gdy zostało ono na nowo - i znacznie lepiej - wydane przez J. Sawickiego w Iura Masoviae Terrestria ${ }^{35}$. Starsze edycje źródłowe wykorzystano również w przypadku statutów: Kazimierza Wielkiego i warckiego (Starodawne prawa polskiego pomniki) ${ }^{36}$ oraz konstytucji sejmowych z lat 1496 i 1588 (Volumina legum) ${ }^{37}$.

W omawianym artykule pominięto całkowicie inne typy źródeł - przede wszystkim praktyki sądowej. Odniesienia do stosowania prawa pojawiają się za dotychczasową literaturą i dotyczą przede wszystkim wcześniejszego średniowiecza. Nie zostały natomiast spożytkowane - dość licznie wydane - średniowieczne kodeksy dyplomatyczne i księgi sądowe (rejestry nieruchomości - jak chce autor): ziemskie i grodzkie oraz miejskie, nie wspominając już o późniejszych, zachowanych w zbiorach archiwalnych. Może to dziwić w artykule poniekąd im właśnie poświęconym. Jego treść wzbogacić mogły też prace dawnych prawników: Stanisława Łochowskiego ${ }^{38}$ i Marcina Paciorkowskiego ${ }^{39}$ - poświęcone procesowi granicznemu, oraz Adama Żydowskie$\mathrm{go}^{40}$ - dotyczący tzw. staropolskiej hipoteki.

Przy tak skromnym wykorzystaniu bazy źródłowej, chociaż można było spodziewać się rzetelnego przedstawienia aktualnego stanu badań problematy-

${ }^{35}$ Iura Masoviae ..., t. I-III, Warszawa 1972-1974. Uwagi i uzupełnienia: A. Wolff, [rec.] „Iura Masoviae Terrestria”, „Kwartalnik Historyczny”, t. LXXXII, 1975, z. 1, s. 120-131.

36 Pełne wydanie Statutów Kazimierza Wielkiego: Statuty Kazimierza Wielkiego, oprac. O. Balzer, wyd. Z. Kaczmarczyk, M. Sczaniecki, S. Weymann, „Studia nad Historią Prawa Polskiego”, t. XIX, Poznań 1947; Statuty Kazimierza Wielkiego. Część II: Statuty wielkopolskie, oprac. L. Łysiak, „Studia nad Historią Prawa Polskiego”, t. XXII, Warszawa-Poznań 1982. Statut warcki: Polskie statuty ziemskie $w$ redakcji najstarszych zwodów (Syntagmata), oprac. L. Łysiak, S. Roman, Wrocław-Kraków 1958, s. 117-129.

${ }^{37}$ Nowsze wydanie: Volumina Constitutionum (dalej: VC), t. I, vol. 1, wyd. S. Grodziski, I. Dwornicka, W. Uruszczak, Warszawa 1996; t. II, vol. 2, wyd. S. Grodziski, Warszawa 2008.

${ }^{38}$ S. Łochowski, Processus iudiciarius granicialis Regni Poloniae, Cracoviae 1641.

${ }^{39}$ M. Paciorkowski, Regulae processus granicialis, Częstochowa 1749. Nie uwzględniono również opracowania Cezarego Kunderewicza, zawierającego omówienie obu traktatów, Dzieła Stanisława Łochowskiego i Marcina Paciorkowskiego o polskim procesie granicznym, Warszawa 1956.

${ }^{40}$ A. Żydowski, Potioritas et nonnullae dispunctionis iuris, Varsaviae 1631. Fragment pracy A. Żydowskiego spożytkowano na s. 115, w przyp. 48. Zawiera on cytat z opracowania Walentego Dutkiewicza poświęconego hipotece w Królestwie Polskim, w którym przytoczono właśnie Potioritas Żydowskiego (zresztą niedokładnie w porównaniu z egzemplarzem dziełka Żydowskiego przechowywanym w Bibliotece Uniwersytetu Warszawskiego); W. Dutkiewicz, Prawo hipoteczne w Królestwie Polskim, Warszawa 1850, s. 9. W artykule odsłano do pracy Dutkiewicza, nie wskazując, że oryginalnym autorem ustępu jest Żydowski. 
ki ksiąg sądowych, procesu granicznego oraz zastawów. Autor oparł się jednak w dużej mierze na - niekiedy mocno już przestarzałych - XIX-wiecznych i pochodzących z początków XX w. opracowaniach prawnych i historycznoprawnych. Trzeba przyznać, że dodał nieco - przede wszystkim prawniczej - literatury powojennej (opracowanie prawa rzeczowego Jana Wasilkowskiego, praca poświęcona hipotece w Królestwie Polskim Włodzimierza Wójcikiewicza) ${ }^{41}$ i nowszej (prace T. Staweckiego) ${ }^{42}$. Pominięto cały dorobek naukowy dyplomatyki, archiwistyki i historii prawa w zakresie ksiąg sądowych. Przede wszystkim wskazać tu można prace: Oswalda Balzera ${ }^{43}$, Przemysława Dąbkowskiego $^{44}$, Janiny Bieleckiej ${ }^{45}$ i Janusza Łosowskiego ${ }^{46}$. Temat zyskać mógł także przy wykorzystaniu rezultatów badań prowadzonych nad kancelarią i księgami centralnymi ${ }^{47}$. Dawne wnioski dotyczące prawa rzeczowego na Mazowszu książęcym zostały zmodyfikowane przez - nieuwzględnioną w artykule - gruntowną monografię Stanisława Russockiego ${ }^{48}$. Wielu pomyłek zapewne można byłoby uniknąć, gdyby autor sięgnął do szczegółowych studiów: Zygfryda Ry-

${ }^{41}$ J. Wasilkowski, Prawo rzeczowe w zarysie, Warszawa 1957; W. Wójcikiewicz, Prawo hipoteczne Królestwa Polskiego, Wrocław-Warszawa-Kraków 1967.

${ }^{42}$ T. Stawecki, Rejestry nieruchomości, księgi hipoteczne i księgi wieczyste od czasów najdawniejszych do XX wieku, „Studia Iuridica”, t. XL, 2002, s. 167-186; idem, Rejestry publiczne..., passim.

${ }^{43}$ O. Balzer, Kancelarie i akta grodzkie w wieku XVIII, Lwów 1882 [nadbitka z „Przewodnika Naukowego i Literackiego"].

${ }^{44}$ Spośród licznych prac tego uczonego poświęconych księgom i palestrze wskazać można: P. Dąbkowski, Palestra i księgi sądowe trembowelskie za czasów polskich, Lwów 1920; idem, Palestra i księgi sadowe sanockie $w$ dawnej Polsce, „Pamiętnik Historyczno-Prawny”, t. 1, z. 6, Lwów 1925; idem, Palestra i księgi sadowe ziemskie..., s. 99-207.

${ }^{45}$ J. Bielecka, Organizacja i działalność..., s. 129-152; eadem, Kancelaria grodzka ..., s. 119$-153$.

${ }^{46}$ J. Łosowski, Kancelaria grodzka..., passim. Pełny przegląd stanu badań nad kancelariami i księgami grodzkimi i ziemskimi, zob. idem, Osiagnięcia i potrzeby w zakresie badań nad dziejami kancelarii sądów i urzędów szlacheckich praz wiejskich w dawnej Polsce, [w:] Belliculum diplomaticum IV Thorunense. Dyplomatyka staropolska - stan obecny i perspektywy badań, red. K. Chorążyczewski, J. Tandecki, Toruń 2011, s. 100-104.

${ }^{47}$ W. Krawczuk, Metryka Koronna za Zygmunta III Wazy. Początki Archiwum Koronnego Warszawskiego za Zygmunta III Wazy w świetle spisów z 1620 i 1627 roku, Kraków 1995; idem, Metrykanci koronni: rozwój registratury centralnej od XVI do XVIII wieku, Kraków 2002; K. Chorążyczewski, Przemiany organizacyjne kancelarii królewskiej u progu czasów nowożytnych, Kraków 2007; A. Wolff, Metryka Mazowiecka. Uktad pierwotny, sposób rejestracji, Warszawa 1929; E. Suchodolska, Kancelarie na Mazowszu w latach 1248-1345. Ośrodki zarzadzania i kultury, Warszawa 1977; J. Grabowski, op. cit. Podsumowanie stanu badań nad kancelariami centralnymi: mazowieckimi i koronną zob.: idem, Kancelarie książęce na Mazowszu (XIII-XVI wiek). Stan badań i perspektywy badawcze, [w:] Belliculum diplomaticum II Thorunense. Kancelarie władców na ziemiach polskich $w$ średniowieczu i czasach nowożytnych na tle porównawczym, red. W. Chorążyczewski, J. Tandecki, Toruń 2007, s. 153-169; W. Chorążyczewski, Czego wciąż nie wiemy o kancelariach centralnych dawnej Rzeczypospolitej, [w:] Belliculum diplomaticum IV Thorunense..., s. 47-50.

${ }^{48}$ S. Russocki, op. cit., passim. 
maszewskiego ${ }^{49}$, Józefa ${ }^{50}$ i Jacka ${ }^{51}$ Matuszewskich, Antoniego Gąsiorowskiego $^{52}$, Wacława Uruszczaka ${ }^{53}$, Wojciecha Kulisiewicza ${ }^{54}$, nie wspominając już o dokładniejszym przeanalizowaniu odpowiednich fragmentów syntez historii prawa polskiego ${ }^{55}$.

IV. Liczba wspomnianych pomyłek i nieścisłości jest - jak na dość krótki szkic - znaczna. Niekiedy nie uchodziłyby one nawet studentowi zdającemu egzamin z historii ustroju i prawa polskiego. Wspomniano już o stwierdzeniach, z których wynika, iż w XV w. władcami Polski byli książęta. Do tej kategorii można zaliczyć tezę autora, iż na przełomie XVIII i XIX w. doszło do przeprowadzenia akcji katastralnej „,będącej bezpośrednim skutkiem likwidacji na ziemiach polskich pańszczyzny i uwłaszczenia chłopów" (s. 113)! Aż wstyd przypominać, że proces uwłaszczenia chłopów w zaborze pruskim rozpoczął się w roku 1808 i trwał przez kilka następnych dekad, w Galicji dokonano go w 1848 r., a na ziemiach wchodzących w skład zaboru rosyjskiego w latach 1861-1864. Trudno zgodzić się z twierdzeniem, aby do zawarcia prawnie skutecznej umowy sprzedaży nieruchomości wystarczały: posiadanie zbywanego prawa, zdolność prawna i przewidziana prawem forma (s. 106). Zarówno dawniej, jak i obecnie, do dokonania czynności prawnych wymagana jest zdolność do czynności prawnych, która jest przecież pojęciem węższym od zdolności prawnej. W prawie staropolskim z możliwością dokonania alienacji dóbr ziemskich związane było obostrzenie dotyczące wieku: wymagano osiągnięcia granicy „lat dojrzałych”. Autor pogubił się także w średniowiecznych sposobach umacniania zobowiązań (s. 108). Błędne jest wskazanie ewikcji jako gwarantowanej sumy, która miała stanowić rodzaj finansowego zabezpieczenia zawartej umowy. Jest to bowiem typowa klauzula umowna ustanawiająca zakład (va-

${ }^{49}$ Z. Rymaszewski, Zastaw..., s. 113-134; Z badań nad organizacja sąów prawa polskiego w średniowieczu. Woźny sądowy, Warszawa 2008 (dalej cyt.: Woźny sądowy); idem, Z badań nad organizacja sądów prawa polskiego w średniowieczu. Czynności woźnego sądowego, Warszawa 2010 (dalej cyt.: Czynności woźnego).

50 J. Matuszewski, Aqua abrenuntiationis. Studium ze średniowiecznego prawa prywatnego, [w:] idem, Pisma wybrane, t. I, Łódź 1999, s. 137-207 (przedruk z: CPH, t. IV, 1952, s. 164-237); idem, Rękojmia w rozumieniu Kodeksu Zobowiązań i rękojmia w dawnej polszczyźnie, [w:] idem, Pisma wybrane, t. II, Łódź 2000, s. 115-132 (przedruk z: CPH, t. XV, 1963, z. 1, s. 203-222); idem, Ewikcja i rękojmia, [w:] idem, Pisma wybrane, t. III, Łódź 2001, s. 113-146 (przedruk z: CPH, t. XV, 1963, z. 2, s. 125-156).

${ }^{51}$ J. S. Matuszewski, op. cit., passim.

${ }^{52}$ A. Gąsiorowski, Tak zwane prawo wieczności w dawnej Polsce, CPH, t. XXII, 1970, z. 2, s. 31-57.

${ }^{53}$ W. Uruszczak, Korektura praw z 1532 r. Studium historyczno-prawne, t. I, Kraków 1990.

${ }^{54}$ W. Kulisiewicz, Zaruka (vadium) w prawie litewskim XV-XVII wieku, Warszawa 1993.

${ }^{55}$ Historia państwa ..., t. I, s. 289-303, 502-505; t. II, Warszawa 1966, s. 291-292, 408-409; S. Płaza, Historia prawa w Polsce na tle porównawczym, cz. I, Kraków 2002, s. 287-294 (wyd. 2 popr.). 
dium) - nie zaś ewikcję ${ }^{56}$. Jako ewikcję należy natomiast uznać: oświadczenie sprzedajacego, w którym udzielał on kupującemu rękojmi na wypadek, gdyby ktokolwiek kwestionował jego tytuł do nabytej własności ${ }^{57}$. Z kolei termin rękojmia miał w dawnym prawie inne znaczenie, odnoszące się do osobistego poręczenia umowy nie zaś - swoistej odpowiedzialności za wady prawne rzeczy $^{58}$. Podsumowując: artykułowa ewikcja była zakładem, rękojmia - ewikcja, a w rzeczywistości dawne rękojemstwo - jeszcze innym środkiem zabezpieczania zobowiązań. Trudno też uznać za zwykły lapsus calami treść przypisu 30, w którym autor omawia art. 13 statutu wareckiego z 1420 r. (s. 111). Chodzi oczywiście o statut wydany na sejmie w wielkopolskiej Warcie w roku 1423, nie zaś - mazowieckiej Warce 3 lata wcześniej ${ }^{59}$.

Wskazane wyżej błędy rzeczowe wydają się szczególnie rażące w artykule naukowym. Lista kontrowersyjnych - i budzących sprzeciw - a niekiedy wprost błędnych tez jest jednak znacznie dłuższa. Jako egzemplifikacja służyć może bliższe przyjrzenie się twierdzeniom autora poświęconym: przeniesieniu własności, księgom sądowym oraz zastawom (bez dzierżenia i hipotece).

Już w drugim akapicie artykułu pojawia się teza o pojawieniu się pisemnych umów przeniesienia własności ok. 1000 r. (s. 105). Autor nie wskazuje, rzecz jasna, żadnego dokumentu z X czy XI w., odsyła natomiast do przestarzałego opracowania J.W. Bandtkie-Stężyńskiego z I połowy XIX w. ${ }^{60}$ oraz

${ }^{56} \mathrm{O}$ funkcjach i praktyce stosowania zakładu w umowach w prawie litewskim, zob. W. Kulisiewicz, op. cit., s. 112-139.

${ }^{57} \mathrm{Na}$ temat zachodźstwa (ewikcji, intercesji): J. Łączyński, Kompendium sądów Króla Jego Mości, wyd. Z. Kolankowski, [w:] Zapomniany prawnik XVI wieku Jan Łączyński i jego „Kompendium sądów Króla Jego Mości". Studium z dziejów polskiej literatury prawniczej, Toruń 1960, s. 100-101. Krótka charakterystyka: P. Dąbkowski, Prawo prywatne..., t. II, s. 491-492; Historia państwa ..., t. I, s. 314; J. Matuszewski, Ewikcja ..., s. 113-118.

${ }^{58}$ Zob. P. Dąbkowski, Rękojemstwo w polskim prawie średniowiecznem, Lwów 1904, passim. Porównanie terminów rękojemstwa w dawnej Polsce i w okresie międzywojennym, J. Matuszewski, Rękojmia ..., s. 120-132.

59 Powstanie statutu warckiego, czy też - ściślej mówiąc: statutów krakowskiego i warckiego - było przedmiotem dyskusji, zob. A. Kłodziński, O powstaniu statutu warckiego, „Czasopismo Prawnicze i Ekonomiczne”, t. XXX, 1936, s. 532-556; S. Roman, O czasie wydania statutu warckiego, CPH, t. III, 1951, s. 155-191; W. Uruszczak, O genezie i dacie statutu krakowskiego Władystawa Jagielty, CPH, t. XX, 1968, z. 2, s. 59-65. Omówienie stanu badań: idem, Z badań nad statutem warckim z 1423 roku, [w:] Parlamentaryzm i prawodawstwo przez wieki. Prace dedykowane Prof. Stanisławowi Płazie w siedemdziesiąta rocznicę urodzin, red. J. Malec, W. Uruszczak, Kraków 1999, s. 135-147.

${ }^{60}$ J.W. Bandtkie-Stężyński, Historya prawa polskiego, Warszawa 1850, s. 224. Głównym argumentem Bandtkie-Stężyńskiego, przedstawionym we wcześniejszym artykule o notariacie, był dokument działu Lubomierza dokonanego przed palatynem Sieciechem w 1088 r., idem, O notaryacie czyli pisarstwie aktowem kraiowem, tak dawniejszem, iako i nowszem, „Pamiętnik Warszawski”, t. 3, 1815, s. 333. Jest to jednak oczywisty falsyfikat, o czym świadczy chociażby tytulatura Sieciecha (palatinus cracoviensis), czy urzędy sprawowane przez wzmiankowane w akcie osoby (vexilifer terrae cracoviensi, dapifer cracoviensis). O postaci Sieciecha zob. J. Kurtyka, Sieciech 
syntezy historii państwa i prawa, w której takie stwierdzenie nie pada ${ }^{61}$. Nieścisłe jest zdanie o wymaganym potwierdzeniu alienacji nieruchomości przez panującego w XIV-XV w. (s. 105-106). W Królestwie Polskim w XIV w. uprawnienia do konfirmacji - w zależności od regionu - uzyskali starostowie lub sąd ziemski ${ }^{62}$. Władcy mazowieccy utrzymywali to uprawnienie dhużej, lecz dotyczyło ono przede wszystkim dóbr nadanych ${ }^{63}$. Nieprawidłowe jest także omówienie procesu alienacji nieruchomości, w którym wpierw miało dochodzić do wwiązania nabywcy, a następnie do wywiązania (wzdanie, rezygnacja) dotychczasowego właściciela (s. 106). Kolejność, przynajmniej od XIV w. była odwrotna: najpierw sprzedający dokonywał rezygnacji, później zaś dopiero następowała intromisja nabywcy ${ }^{64}$. Pewne zastrzeżenia można podnieść także do wzmianek dotyczących roli woźnych przy intromisji (s. 106). Przesadą jest zaliczanie ich do „miejscowej władzy”, zważywszy na dość niski status społeczny tej grupy (często wywodzili się oni z nieszlachty i działali na rzecz swoich panów feudalnych $)^{65}$. Dalszych badań wymaga też kategoryczne stwierdzenie o karach grożących za dokonanie alienacji „bez udziału przedstawicieli władzy" (s. 106): Z. Rymaszewski wykazał niedawno, że jednak było to możliwe ${ }^{66}$. Podobne wątpliwości towarzyszą wzmiankowanym warunkom: obecności dwóch świadków szlachty oraz konieczności udziału sąsiadów w obchodzie nabywanej nieruchomości ${ }^{67}$. Na marginesie można też zauważyć, że stwierdzenie: ,dokonanie wwiązania prowadzącego do intromisji" (s. 109) jest pleonazmem: polskim odpowiednikiem terminu intromisio było właśnie słowo wwiązanie. Niewątpliwie przydałoby się także wyraźne zaznaczenie, iż już w średniowieczu zanikła część najstarszych,

palatyn, [w:] Polski Stownik Biograficzny, t. XXXVI, Kraków-Warszawa 1995-1996, s. 495-509 (tamże obszerna literatura).

${ }^{61} \mathrm{~J}$. Bardach za to wyraźnie stwierdza: „Forma pisemna nie była zrazu znana z powodu nieznajomości sztuki pisania. Pierwsze zachowane polskie dokumenty datują się z XII w., a w ciągu w. XIII tak się upowszechniły, że można już mówić o praktyce spisywania umów dotyczących nieruchomości", Historia państwa ..., t. I, s. 308. O dokumencie jako środku dowodowym mowa jest w odniesieniu do wieków XII-XIII, ibidem, s. 356. Tym bardziej dziwić może odesłanie przez D. Felcenlobena na s. 229 syntezy, gdzie omówiono pierwsze przywileje dla duchowieństwa. Być może - per analogiam z Czechami i Węgrami - nieliczne dokumenty fundacyjne wystawiane były przez pierwszych Piastów, W. Semkowicz, Uwagi o początkach dokumentu polskiego, „Kwartalnik Historyczny", t. XLIX, 1935, z. 1, s. 21-26.

${ }^{62}$ Analiza tego procesu, zob. A. Gąsiorowski, Tak zwane...., s. 36-46.

${ }^{63}$ S. Russocki, op. cit., s. 77-78, 216-224.

${ }^{64}$ Omówienie tyczące zarówno prawa mazowieckiego, jak i koronnego zob. ibidem, s. 216-227.

${ }^{65} \mathrm{Na}$ temat pochodzenia woźnych i ich więzi z właścicielami wsi ostatnio: Z. Rymaszewski, Woźny sądowy, s. 85-88, 95-99 (tamże dalsza literatura).

${ }^{66}$ Z. Rymaszewski, Czynności woźnego, s. 221. Twierdzenie P. Dąbkowskiego o istnieniu takich kar opiera się na jednej - pośredniej - wzmiance z sądu halickiego z 1463 r., Akta grodzkie i ziemskie z czasów Rzeczypospolitej Polskiej z Archiwum tak zwanego bernardyńskiego we Lwowie, t. XII, Lwów 1887, s. 297, poz. 3072.

${ }^{67}$ Praktyka odmienna, zob. Z. Rymaszewski, Czynności woźnego..., s. 231-233. 
symbolicznych czynności towarzyszących wwiązaniu i rezygnacji (zeskakiwanie z gruntu, aqua abrenuntiationis $)^{68}$. Na podstawie lektury artykułu można bowiem odnieść wrażenie, iż te archaiczne sposoby umacniania zobowiązań utrzymywały się co najmniej do końca średniowiecza.

Wśród różnych wzmianek dotyczących ksiąg sądowych zwracają uwagę niekonsekwencje przy określaniu momentu ich powstania. W artykule wskazuje się na: wiek XIV - regestry sq̨dowe (tabulae iudicii) z 1322 r. (s. 107) ${ }^{69}$ oraz księgi ziemi kujawskiej pochodzace z 1381 roku (s. 110) ${ }^{70}$; przełom XV i XVI w. ${ }^{71}$; czy nawet koniec wieku XVI ${ }^{72}$.

Za nieprawidłowy należy uznać podział ksiąg na: sądowe, grodzkie i ziemskie (s. 114, 118). Wynika z niego, że księgi grodzkie i ziemskie nie były księgami sądowymi, Być może autor uznał, że prowadził je tajemniczy urząd rejestrowy (wzmiankowany na s. 111). Truizmem będzie przypomnienie, że dekrety, inskrypcje, relacje i manifestacje były seriami rzeczowymi tych samych ksiąg sądowych, prowadzonych przez kancelarie, czyli organy pomocnicze sądów grodzkich i ziemskich ${ }^{73}$. Nie bardzo też wiadomo, czym powodowane jest twierdzenie: ,prowadzone księgi koncentrowały się przede wszystkim na rejestrowaniu i identyfikowaniu osób, którym przysługiwało określone prawo rzeczowe" (s. 111). Sądzić należy, że raczej chodziło o rejestrację czynności prawnych, nie zaś osób ich dokonujących - najczęściej w tytule wpisu oznaczano nieruchomość, nie zaś osobę. Co ważniejsze, funkcje ksiąg wykraczały daleko poza ten wąsko zarysowany obszar. Wpi-

${ }^{68}$ Zob. J. Matuszewski, Aqua abrenuntaitionis..., s. 148, 195-196; P. Dąbkowski, Prawo prywatne..., t. II, s. 196-197. J. Adamus, Wzdanie a symbol ,aquae abrenuntiationis, CPH, t. VII, 1955 , z. 1, s. 416-417.

${ }^{69}$ D. Felcenloben w przypisie 10 błędnie odsyła do stron 373-374 pracy T. Staweckiego o rejestrach publicznych. W rzeczywistości T. Stawecki umieścił informację o tabulae iudicii we wcześniejszym artykule, Rejestry nieruchomości..., s. 178, odsyłając do stron 373-374 pierwszego tomu syntezy państwa i prawa J. Bardacha. W nim pojawiła się wzmianka o tabulae iudicii z zaznaczeniem, że wpisywano do nich terminy pozwów, Historia państwa i prawa...., s. 373. Stąd też twierdzenie D. Felcenlobena: „W prowadzonych wówczas regestrach sądowych (tabulae iudicii) były odnotowywane wzmianki o dokonanych przed sądem aktach sprzedaży gruntów, tzw. wzdaniach (resignatio)" jest nieuprawnione. Należy sądzić, iż doszło do pomylenia pojawiających się w I połowie XIV w. regestrów pozwów $\mathrm{z}$ - w miarę już rozwiniętymi - księgami sądowymi z końca tego wieku.

${ }^{70} \mathrm{Tu}$ też należy sprostować pewne drobne błędy. Po pierwsze: niedawne ustalenia Janusza Bieniaka nieco zmodyfikowały datację tych ksiąg. Najstarsze zapiski pochodzą z roku 1397, a wzmianki o księgach brzeskich - z 1389 r., J. Bieniak, Najstarsze kujawskie księgi ziemskie (1397-1408), Warszawa 2007, s. 9-11. Po drugie: jest subtelna różnica między księgami ziemi kujawskiej, a kujawskimi księgami ziemskimi.

71 „Instytucja hipoteki [...] pojawiła się w prawie polskim wraz z księgami ziemskimi i grodzkimi na przełomie XV i XVI w.” (s. 110-111).

72 „Uchwalone normy ustalające jawność hipoteki, [konstytucja O ważności zapisów z 1588 r. - A. M.] wymuszały tym samym konieczność utworzenia i prowadzenia ksiąg publicznych (sądowych, grodzkich, ziemskich" (s. 114).

${ }^{73}$ Spory o definicję kancelarii grodzkiej omówił J. Łosowski, Kancelaria grodzka ..., s. 111-115. 
sywano w nie przecież m.in.: wyroki sądowe, czynności procesowe, relacje urzędowe, protestacje, akty publiczne, akta sejmikowe, popisy pospolitego ruszenia. Teza o tym, jakoby państwo za pomocą ksiąg sądowych „posiadało w pewnym zakresie możliwość kontrolowania czynności cywilnoprawnych dotyczących praw do przenoszenia nieruchomości” (s. 111) jest mocno kontrowersyjna, tym bardziej że ani nie została rozwinięta, ani w żaden sposób udokumentowana. Zgodzić się z nią można w zakresie egzekwowania norm zakazujących nieszlachcie nabywania ziemi. Jednak jej wyeksponowanie jako jednej z głównych funkcji ksiąg ma ewidentnie proweniencję marksistowską $^{74}$. Zastrzeżenia można też mieć do określenia Metryki Koronnej i Metryki Mazowieckiej jako kancelarii rejestrowej (s. 107). Problem definicji Metryki Koronnej niejednokrotnie pojawiał się już w literaturze przedmiotu. Węższa ogranicza ją do ksiąg prowadzonych przez kancelarię; szersza traktuje jako odrębną część kancelarii koronnej o funkcjach archiwalnych, registratury i urzędu wiary publicznej ${ }^{75}$.

Problemów przysparza też interpretacja norm dotyczących ksiąg sądowych, zawartych w konstytucjach z II połowy XVIII w. Nie sposób się zgodzić ze stwierdzeniem: „w 1775 r. Sejm przyjął ustawę wprowadzającą podwójny system ksiąg wieczystych, zwanych protokołami” (s. 118). W żadnym stopniu nie były to bowiem księgi wieczyste, a zatem ustanawiane dla konkretnej nieruchomości, lecz księgi sądowe z prawem wieczności, prowadzone dla poszczególnych powiatów lub okręgów starostw ${ }^{76}$. Protokół zaś nie był podwójnym systemem ksiąg, tylko jedną z dwóch podstawowych serii formalnych tego systemu. Pełnił on rolę swoistego brudnopisu, z którego przenoszono wpisy - już w pełnej formie - do drugiej serii ksiąg, czyli indukty. Podwójny system prowadzenia ksiąg pojawił się już w XVI w., choć rzeczywiście w praktyce w II połowie XVII w. coraz częściej z niego rezygnowano ${ }^{77}$. Wspominana konstytucja nakazywała wyodrębnienie z protokołów rzeczowej serii wpisów zawierających umowy pożyczek zabezpieczonych zastawem ${ }^{78}$.

74 Teza powyższa została zaczerpnięta z pracy J. Wasilkowskiego, Prawo rzeczowe w zarysie, Warszawa 1957, s. 317. Podstawową funkcją ksiąg w zakresie obrotu cywilnoprawnego było przede wszystkim zwiększenie jego ochrony i pewności prawa, stąd - padające w tej pracy - wzmianki o nich jako narzędziu opresji feudalnej są dziś mocno przestarzałe.

75 Spory definicyjne zob. W. Krawczuk, Metrykanci..., s. 13-14.

${ }^{76} \mathrm{Na}$ marginesie można zauważyć, że o ile księgi ziemskie były prowadzone osobno dla każdego powiatu, o tyle grodzkie mogły obejmować cały teren podległy jurysdykcji starosty. Jako przykład można wskazać księgi grodu płockiego z II połowy XVI i I połowy XVII w., obejmujące całe województwo złożone z 2 ziem (8 powiatów).

77 J. Bielecka zwróciła uwagę na to, że w Wielkopolsce powrócono do podwójnego system prowadzenia ksiąg ziemskich w połowie XVIII w., Organizacja i działalność..., s. 138-139, 144-146; zob. też J. Łosowski, Kancelaria grodzka..., s. 195-196.

${ }^{78}$ Nakazuiemy wszystkim Grodom, tak w Koronie iako y Litwie, ażeby protokut osobliwy dla wszystkich osób dtugi zaciagaiacych uformowaty, w który protokut żadne inne tanzakcye przyjmowane być nie powinny, tylko dlugi Obywatelow tego Woiewodztwa, Ziemi lub Powiatu, Volumina 
Precyzją nie grzeszy twierdzenie, iż konstytucja z 1768 r. nakazywała przeniesienie wpisu do ksiąg właściwych miejscowo w ciągu roku, a w czasach niepokoju w ciągu roku i 6 tygodni od ustania jego przyczyn (s. 117). Przywoływana norma z konstytucji Złączenie Trybunału Koronnego rzeczywiście wskazywała na drugi z terminów w nadzwyczajnych sytuacjach, lecz jako termin podstawowy naznaczyła rok lub dwa - tyle że sądowe ${ }^{79}$. Twierdzenie, że normy zawarte w tej konstytucji zmierzały „do utworzenia dla każdej nieruchomości unikatowych ksiąg urzędowych" nie znajduje żadnego potwierdzenia w jej tekście: stosowny fragment dotyczył przecież obowiązku i terminu przenoszenia wpisów do ksiąg właściwych miejscowo. Niestety, autor nie podał żadnych podstaw - źródłowych lub pochodzących z literatury przedmiotu - dla swej bardzo daleko idącej tezy.

Omówienie fragmentu artykułu dotyczącego zastawów zacząć należy od anachronicznej - przejętej od K. Dunina - terminologii ${ }^{80}$ : zastaw prosty i pod przypadkiem (sic! - winno być: przepadkiem). Co najmniej od kilkudziesięciu lat przyjęto operowanie terminami: zastaw użytkowy czysty (antychretyczny) i zastaw na upad ${ }^{81}$. Za całkowicie mylne należy uznać twierdzenie: ,ostateczny termin wykupu zastawionych gruntów odpowiadał terminowi przedawnienia" ze wskazaniem, że wynosił on na Mazowszu rok i 6 tygodni lub 3 lata (s. 108). Autor przywołuje tu ustalenia K. Dunina, nie zauważając przy tym, iż dotyczą one terminów realizacji prawa bliższości, nie zaś - wykupu zasta$\mathrm{wu}^{82}$. Ustalenie terminów spłaty zobowiązania - jeśli w ogóle decydowano się na ten krok - zależało przede wszystkim od stron umowy. Warto przy tym zauważyć, że tego typu klauzule umowne - tak w prawie mazowieckim, jak i koronnym - były bardzo różnorodne: mogły - na przykład - ustanawiać zastaw wieczysty $\mathrm{z}$ oznaczonym raz $\mathrm{w}$ roku ewentualnym terminem wyku-

legum (dalej: VL), wyd. J. Ohryzko, Petersburg 1859-1860, t. VIII, s. 111. Powyższe postanowienie zostało rozszerzone w następnym roku ordynacją Rady Nieustającej o papierze stemplowym, w której nakazano prowadzenie trzech różnych serii protokołów: zapisów i kwitów na papierze stemplowym, drugi - dla długów, weksli i przeniesienia oblat z innych ksiąg, trzeci zaś - dla transakcji wieczystych. Nie wszędzie powyższe normy od razu wprowadzono w życie, np. w grodzie chełmskim wymagane protokoły założono w roku 1779, zob. J. Łosowski, Kancelaria grodzka..., s. 202.

${ }^{79}$ Iż tranzakcye wszelkie, tak wieczyste, iako i doczesne, ręczne, dożywocia i zapisy w obcych Grodach lub Ziemstwach zeznane, a podlug pomienionego Statutu W. X. Lit. na pierwszych lub powtornych Rokach, w czasie pokoiu, do xiag własnego Woiewodztwa, lub Powiatu, gdzie się dobra znayduia, a w czasach niepokoiu lub grassuiqcego powietrza, po uspokoieniu tego, w rok y sześć niedziel nie będa przeniesione, takowe tranzakcye niszczemy i za nieważne w każdym Sądzie mieć chcemy, VL, t. VII, s. 331.

${ }^{80}$ Por. K. Dunin, op. cit., s. 179.

${ }^{81}$ Szerszego omówienia różnych klasyfikacji zastawów dokonał J.S. Matuszewski, op. cit., s. 11-18, zob. też. Z. Rymaszewski. Zastaw ..., s. 119-123; Historia państwa ..., t. I, s. 303, 503-504; S. Płaza, op. cit., s. 288-289.

${ }^{82}$ K. Dunin, op. cit., s. 157. 
pu, regulować zarówno maksymalny, jak i minimalny czas trwania zastawu ${ }^{83}$. W prawie mazowieckim istniało ograniczenie - ostatecznie zniesione przez Ekscepta mazowieckie - w postaci 30-letniego terminu zasiedzenia nieruchomości przez zastawnika: po upływie tego terminu dobra przechodziły na jego własność ${ }^{84}$.

Przechodząc do hipoteki, warto zwrócić uwagę na ponowne niekonsekwencje dotyczące ustalenia momentu jej początków na ziemiach polskich. W artykule pojawiają się dwa terminy: ,na ziemiach polskich stosowana była powszechnie z końcem XIV wieku” (s. 110) oraz „pojawiła się w prawie polskim wraz z księgami ziemskimi i grodzkimi na przełomie XV i XVI w." (s. 110-111). Co ciekawe, w obu przypadkach przypis odsyła do artykułu O. Balzera zamieszczonego w „Gazecie Sądowej Warszawskiej” ${ }^{85}$. W nim znakomity lwowski uczony milczy jednak na temat rzekomego wprowadzenia ksiąg i hipoteki dopiero na przełomie XV i XVI w. ${ }^{86}$ Jako mocno enigmatyczna rysuje się myśl zawarta w zdaniu: „Na mocy zawartego kontraktu hipotecznego wierzyciel uzyskiwał gwarancję bezpieczeństwa wierzytelności zabezpieczonych na majątku rzeczowym z pierwszeństwem jego egzekucji, pod warunkiem jego ujawnienia $\mathrm{w}$ aktach wieczystych właściwych in foro proprii districtus (z uwagi na właściwość miejscową urzędu rejestrowego tzw. położenie w dobrach pozwu)" (s. 111). Zrozumienia sensu zdania nie ułatwiają niejasności terminologiczne i meandry stylistyczne ${ }^{87}$. Dodatkowo można podnieść, iż w średniowieczu zasada pierwszeństwa ze względu na

${ }^{83}$ Por. K. Dunin, op. cit., s. 179-180; S. Russocki, op. cit., s. 265-268; Z. Rymaszewski, Zastaw..., s. 119-120, 128-129; J.S. Matuszewski, op. cit., s. 38-40.

${ }^{84}$ K. Dunin, op. cit., s. 179; S. Russocki, op. cit., s. 268-269, art. 26 Eksceptów w redakcji Volumina Constitutionum, t. II, vol. 1, s. 387.

${ }^{85}$ O. Balzer, Hypoteka $w$ dawnem ustawodawstwie polskiem, „Gazeta Sądowa Warszawska”, 1888 (r. XVI), nr 29, s. 475-481.

${ }^{86}$ Pada za to stwierdzenie: ,początku hipoteki polskiej nie można datować dopiero od r. 1588, gdyż, jak już poprzednio, ślady tej instytucji dadzą się u nas wykazać już wieku XV”, ibidem, s. 476. W nowszych badaniach nad zastawami wskazuje się koniec XIV w. jako moment pojawienia się zastawu bez dzierżenia, Z. Rymaszewski, Zastaw..., s. 123; J.S. Matuszewski, op. cit., s. 44. Na początek XVI w. wskazywał natomiast nie O. Balzer, lecz W. Dutkiewicz, op. cit., s. 3.

${ }^{87}$ Pewien problem związany jest z pojęciem majątku rzeczowego. Podstawowym jest podział rzeczy na ruchome i nieruchome, a w średniowieczu istotny był także podział nieruchomości na dobra nabyte i dziedziczne - czy zatem zabezpieczenie wierzytelności na majątku rzeczowym obejmować miało wszystkie kategorie? Natomiast z użycia zaimka ,jego” wynika, że egzekucji podlega kontrakt hipoteczny, nie zaś wierzytelność, czyli zobowiązanie strony umowy. Z kolei ujawnienie we właściwych aktach w sądzie właściwego powiatu/ ziemi (in foro proprii districtus) jest tautologią, skoro akta były prowadzone przez sądy zgodnie z właściwością terytorialną. Pozornie błahe przestawienie szyku zdania całkowicie wypaczyć może sens instytucji prawnej, czego przykładem jest stwierdzenie: $t z w$. położenie $w$ dobrach pozwu (dobitniej sformułowane w następnym zdaniu: Położenie w tzw. dobrach pozwu). Czym są wspomniane dobra pozwu, oraz: co właściwie w nich kładziono, już nie wyjaśniono. Oczywiście chodzi tu o położenie pozwu na dobrach - jedną z czynności podejmowanych przez woźnego w trakcie pozwania strony. 
moment wpisu zobowiązania do ksiąg, nie była jedyną, lecz współistniała z innymi zasadami dochodzenia roszczeń zabezpieczonych hipoteką (np. pierwszeństwo liczone wedle momentu złożenia pozwu) ${ }^{88}$. Większego sensu pozbawione jest zdanie: „Zastawnik (posiadacz), który nie chciał dopuścić do egzekucji ze swego majątku, winien w przeciągu jednego roku wystąpić z żądaniem zniesienia złożonego wobec wierzyciela pozwu, dowodząc, że wypełnił on swoje wobec niego zobowiązania" (s. 111). Przypomnieć należy, że zdanie to umieszczono $\mathrm{w}$ akapicie dotyczącym zastawu bez dzierżenia, więc posiadaczem dóbr był zastawca, nie zaś zastawnik. Zresztą $\mathrm{w}$ dalszej części zdania można się dowiedzieć, że miał on pozywać wierzyciela, zatem - zastawnika. Intrygująca jest kwestia roszczenia, z którym miałby występować w owym pozwie dłużnik wobec wierzyciela. Jeszcze ciekawiej wypada sugestia, że po wypełnieniu zobowiązania, dłużnik miał zwracać się do wierzyciela z żądaniem zniesienia pozwu - nie znano wówczas takiej instytucji, lecz przeciw powództwu podnoszono ekscepcje w czasie rozprawy ${ }^{89}$. Przypis przy tym zdaniu odsyła do pracy W. Dutkiewicza, a w niej mowa jest o sytuacji roszczeń różnych wierzycieli wobec siebie po zajęciu dóbr przez jednego z nich - co autorowi najwyraźniej umknęło.

Przedstawiając zasady konstytucji $O$ ważności zapisów, D. Felcenloben uznał, iż „wprowadzała obowiązek ustanowienia prawa rzeczowego, w szczególności wynikającego z zawartego kontraktu bezwarunkowego kupna nieruchomości, umowy warunkowej z prawem odkupu zastawu czy też innych tego rodzaju umów, przed właściwym miejscowo sądem" (s. 114). Po raz kolejny tak daleko idące tezy nie zostały w żaden sposób udokumentowane. Przydałoby się ono niezwykle w tym miejscu, zważywszy, że konstytucja reguluje kwestie związane $\mathrm{z}$ dochodzeniem roszczeń wynikających z umów zabezpieczonych zastawem bez dzierżenia, ani słowem nie wspominając o umowach kupna dóbr ziemskich. Czym natomiast są owe umowy warunkowe z prawem odkupu zastawu, pozostanie owiane mgłą tajemnicy. Warunek jest zastrzeżeniem uzależniającym powstanie lub ustanie zobowiązania od zaistnienia przyszłego i niepewnego zdarzenia. Jak do tego ma się zobowiązanie zabezpieczone zastawem? Komu i w jakim trybie przysługiwać miało prawo odkupu zastawu? Raczej nie zastawcy, bo wówczas pod terminem prawo wykupu zastawu kryje się po prostu wykonania zobowiązania, skutkujące wygaśnięciem zabezpieczającego go zastawu jako prawa o charakterze akcesoryjnym.

${ }^{88}$ Zob. J.S. Matuszewski, op. cit., s. 46-51.

${ }^{89}$ Jest to oczywiste nieporozumienie: $\mathrm{z}$ chwilą spełnienia świadczenia zobowiązanie wygasało, a wraz z nim ustanowiony zastaw. Wierzyciel, który chciałby dochodzić przed sądem ponownego wykonania zobowiązania, narażał się na peremptoryjny zarzut procesowy (exceptio rei finitae), zob. J. Rafacz, op. cit., s. 154; S. Kutrzeba, Dawne polskie prawo..., s. 87-88; W. Uruszczak, Korektura praw..., s. 140; A. Moniuszko, op. cit., s. 246. 
Mocno kontrowersyjne jest formułowanie zasady legalizmu (legalności) w odniesieniu do tzw. hipoteki staropolskiej ${ }^{90}$. W artykule uznano, iż oznacza ona możliwość dokonania wpisu do ksiąg sądowych ,jedynie na wyłączny wniosek osoby, której prawa ujawnione były w rejestrze po jego wcześniejszym zbadaniu przez organ prowadzący księgi” (s. 114). Autor dalej - powołując się na ustalenia O. Balzera - stwierdza, że osobą, której przysługiwało takie prawo był dłużnik, a nie osoby trzecie lub ich pełnomocnicy ${ }^{91}$. Problemem podstawowym jest, czy sam fakt, iż osoby trzecie nie były uprawnione do dokonania wpisu ustanawiającego prawo rzeczowe na dobrach, wystarcza do tego, by formułować istnienie zasady legalności. Zakaz działania osób trzecich był ogólną zasadą dawnego postępowania sądowego, zarówno $\mathrm{w}$ procesie skargowym, jak i postępowaniu niespornym ${ }^{92}$. Nie było natomiast żadnej procedury badania zgodności z prawem, czy też podstaw danej czynności prawnej, czyli fundamentalnych elementów zasady legalności w ustawie hipotecznej z $1818 \mathrm{r}^{93}$ Całkowicie pozbawione podstaw jest zaprezentowane $\mathrm{w}$ artykule twierdzenie, iż $\mathrm{w}$ przypadku kolejnego wpisu zastawu do ksiąg sądowych wierzyciel, któremu przysługiwało prawo pierwszeństwa „zobowiązany był zgłosić swoje roszczenia w przeciągu trzech lat od daty jego ujawnienia. Jeżeli tego nie uczynił, tracił swoje prawa na rzecz kolejnego uprawnionego wierzyciela" (s. 115). Sądzić należy, że pogląd wynika z błędnej interpretacji części konstytucji z 1588 r.: „I choćby kto przezyski i possesyą za pośledniejszym zapisem otrzymał, tedy pierwszego zapisu summa i przezyski mają być ważniejsze i naprzód iść; wyiąwszy gdyby kto był triennalis possessor" 94 . Trzyletni termin przedawnienia prawa pierwszeństwa dotyczył sytuacji, w której wierzyciel przejął już przedmiot zastawu z powodu niespłaconego zobowiązania. Liczony był on od wwiązania w dobra i oznaczał, iż po jego upływie traciło ważność pierwszeństwo ewentualnych „wcześniejszych” wierzycieli ${ }^{95}$. Interpretacja przestawiona w artykule, oprócz ewidentnego pominięcia faktu uzyskania przezysków i posiadania, o których wspominała konstytucja, obarczona jest też pewnym błędem wnioskowania. Jeśli roszczenie byłoby można zgłosić dopiero w momencie jego wymagalno-

${ }^{90}$ Zasada taka pojawia się w niektórych opracowaniach: O. Balzer, Hypoteka ..., s. 479; W. Wójcikiewicz, op. cit., s. 30.

${ }^{91}$ Wydaje się, że prawo do wpisu przysługiwało również wierzycielowi. O. Balzer, odwołując się do sformułowania ubi bona recognoscentis consistunt uznał, że wpisu mógł dokonać tylko zastawca lub jego pełnomocnik. Fragment ten dotyczy jednak tylko przeniesieni wpisu i dalej w konstytucji pada stwierdzenie świadczące o możliwości dokonania wpisu także przez - najbardziej nim zainteresowanego - wierzyciela: per creditorem vel debitorem abo slugę którego z nich, wpisowane wiadomości każdego byly, VC, t. II, vol. 2, s. 70.

${ }^{92}$ Por. O. Balzer, Przewód sądowy..., s. 22-23; W. Uruszczak, Korektura praw..., t. I, s. 127; A. Moniuszko, op. cit., s. 185-186.

${ }^{93}$ Zob. W. Wójcikiewicz, op. cit., s. 67-69.

${ }^{94} \mathrm{VC}$, t. II, vol. 2, s. 70.

${ }^{95}$ Por. J.S. Matuszewski, op. cit., s. 51. 
ści, przy pożyczce udzielonej na okres - powiedzmy - 5 lat, wierzyciel mógłby być pozbawiony możliwości realizacji prawa pierwszeństwa: uległoby ono przedawnieniu, zanim roszczenie stałoby się wymagalne.

V. Poważne obiekcje można mieć także do strony formalnej artykułu. Należy zwrócić uwagę na aparat naukowy: stosowanie najpierw skróconych, a dopiero później pełnych opisów bibliograficznych, błędy w nazwiskach autorów i tytułach prac, niewłaściwe stosowanie odsyłaczy ibidem i op. cit. ${ }^{96}$ Należy też zwrócić uwagę na niewłaściwe użycie porównaj - nader często stosowanego w sytuacji przywoływania dłuższych partii tekstu zaczerpniętych $\mathrm{z}$ innych prac, w których należałoby raczej użyć: za lub na podstawie. Natomiast parafrazowanie całych ustępów z zamieszczeniem na końcu przypisu $\mathrm{z}$ informacją o porównaniu $\mathrm{z}$ inną pracą pozostawia wątpliwości: co jest własną tezą i myślą autora, co zaś - i w jakim stopniu - przejęto od innych badaczy ${ }^{97}$. Całość artykułu sprawia wrażenie dzieła pospiesznie skompilowanego z różnych wcześniejszych fragmentów. Przykładowej analizie poddano punkt I artykułu, składający się z 7 akapitów. Trzeci akapit jest połączeniem w niewielkim stopniu przeredagowanych ustępów z prac K. Dunina i P. Dąbkowskiego. Akapit czwarty jest skróceniem wywodu tego ostatniego autora. $\mathrm{W}$ akapicie piątym pierwsze dwa zdania pochodzą z artykułu T. Staweckiego

${ }^{96}$ Praca K. Dunina: prawidłowy pełny opis bibliograficzny (przyp. 4), po czym ponowny pełny opis, tym razem już z błędem (Dawne prawo mazowieckie, przyp. 18); w opisie skróconym podawana jest poprawnie oraz jako: Dawne prawa (przyp. 16) lub Dawne prawo (przyp. 20, 25. 28). Artykuł O. Balzera o hipotekach pojawia się najpierw z opisem skróconym (przyp. 23, 25, 27), dopiero później z pełnym (przyp. 31). Praca S. Łaguny ma pełny opis w przyp. 4, oraz ponownie w przyp. 35. Podobnie jest w przypadku pracy K. Józefowicza (przyp. 24 oraz 41). Volumina legum pełnego opisu bibliograficznego nie mają w ogóle. Nie wiadomo, na jakich zasadach stosowany jest skrót op. cit. Pojawia się on przy ponownych powołaniach prac: J. Bardacha i A. Parczewskiego. Nie stosuje się go natomiast przy pracach: K. Dunina, O. Balzera i K. Józefowicza. W przypadku prac W. Wójcikiewicza i W. Dutkiewicza przy ponownym opisie zupełnie już niekonsekwentnie zastosowano wpierw op. cit. (przyp. 15, 25, 28, 40, by w dalszej części artykułu przejść do skróconego opisu bibliograficznego (przyp. 41, 43, 45, 48, 51, 57, 58). Zresztą w przypadku pracy Dutkiewicza podano tylko część tytułu (przyp. 17, winno być: Prawo hipoteczne $w$ Królestwie Polskim).W przypisie 7 ibidem odsyła do artykułu P. Dąbkowskiego o zasadzie jawności, zamiast do syntezy prawa prywatnego tegoż autora. Zupełnie za to nie wiadomo, do jakiej pozycji odsyła ibidem $\mathrm{w}$ przyp. 32. Jest to pierwszy przypis w punkcie o oznaczaniu granic, dotyczący znaków granicznych na drzewach. Natomiast przyp. 31 pojawia się jeszcze przy zarysowaniu podstawowej genezy powstania hipoteki, odsyłając do monografii J. Wasilkowskiego poświęconej prawu rzeczowemu oraz artykułu O. Balzera o hipotekach. Autorem pracy Proces graniczny wydanej w $1827 \mathrm{r}$. w Wilnie był Aleksander Korowicki, nie zaś - Korwicki.

${ }^{97} \mathrm{~W}$ całej rozciągłości należy zgodzić się tu ze zdaniem W. Uruszczaka: „W przypadku parafraz może zajść potrzeba umieszczania przypisów informujących o rzeczywistym autorstwie praktycznie po każdym zdaniu. Umieszczenie przypisu tylko na końcu akapitu nie gwarantuje jasnej informacji o osobie autora całej wypowiedzi"; idem, Z takim sposobem uprawiania nauki zgodzić się nie można! Twórczość historyczno-prawna ks. dra Stanisława Tymosza z lat 2003-2008, „Studia z Dziejów Państwa i Prawa Polskiego", t. XIII, 2010, s. 266. 
dotyczącego rejestrów, trzecie z książki W. Wójcikiewicza o hipotece. W szóstym: niewiele zmienione ustępy z artykułu T. Staweckiego i książki W. Wójcikiewicza. Akapit siódmy wydaje się być bardziej samodzielną próbą, zawiera za to - omówione wcześniej - podstawowe błędy dotyczące sposobów umacniania zobowiązań. Do tego - kompilacji nie dokonano zbyt sprawnie. W tekście pojawiają się powtórzenia - przykładowo: zdefiniowanie resignatio pojawia się na s. 106 (za P. Dąbkowskim) i s. 107 (za T. Staweckim). O nakazie przenoszenia $\mathrm{w}$ ciągu roku wpisów do ksiąg z prawem wieczności mowa jest na s. 111, w związku z tym ponowne umieszczenie tej informacji w przyp. 53 (oba za K. Józefowiczem) wydaje się zbędne. W artykule można znaleźć też przepisane archaizmy językowe (statut wartski) ${ }^{98}$, czy też błędy literowe (bona operata zamiast bona onerata). Autorowi zdarza się także nie podawać źródła przytoczonego - z pewnymi niewielkimi zmianami redakcyjnymi - ustępu, co może nosić znamiona plagiatu. Wcześniej zasygnalizowano już takie postępowanie w przypadku akapitu drugiego na s. 111, zawierającego pseudocytat z Volumina legum ${ }^{99}$, stało się też tak w przypadku ustępu zawierającego bona operata ${ }^{100}$. Niewykluczone, że dalsza analiza tekstu artykułu pod kątem niesygnalizowanych zapożyczeń przyniosłaby kolejne tego typu

${ }^{98}$ Por. P. Dąbkowski, Prawo prywatne..., t. II, s. 194.

${ }^{99}$ D. Felcenloben: W 1496 r. Jan Olbracht wprowadzit prawo, zgodnie z którym ,wszelkie inskrypcje ujawnione $w$ księgach grodzkich, w przeciagu jednego roku do właściwych miejscowo ksiag ziemskich winny być przeniesione" [przypis do VL - A. M.]. Zapisany w księgach ziemskich akt przeniesienia lub ustanowienia prawa uzyskiwat w ten sposób cechę wiecznej trwałości (perpetuitatem), a dlug tak zapisany nie podlegat przedawnieniu. Aby uzyskać prawo rzeczowe do nieruchomości niezbędnym było dokonanie wpisu w księgach ziemskich i posiadanie oryginalnego tytutu (s. 111).

K. Józefowicz: Jan Olbracht w r. 1496 (Vol. Legum. T. I str. 118) oświecit to prawo, stanowiac że wszelkie inskrypcje z ksiag grodzkich w przeciagu roku do ksiąg ziemskich przeniesione być winny, które to księgi stanowity już niejako kontrolę dóbr. Zapisany akt do ksiag ziemskich właściwych miat perpetuitatem, to jest wiecznie byt trwaty, i nie byto na dhug $w$ księdze zapisany przedawnienia. [...] Samo wniesienie do księgi nie uwalniało od prezentowania oryginalnego tytulu; aby więc zyskać prawo rzeczowe na nieruchomości, nie dość je było wpisać do ksiag, ale jeszcze trzeba było przedstawić oryginalny tytut, op. cit., s. 6-7.

${ }^{100}$ D. Felcenloben: Wpis $w$ księdze winien precyzyjnie określać tączna sumę zabezpieczonych wierzytelności oraz sam przedmiot realnego zabezpieczenia, a wszystko po to - jak zapisano $w$ ustawie - aby ,...ludzie nie zawodzili się pożyczając pieniądze super bona operata (na dobra obciążone) (s. 115).

T. Stawecki: Ustawa z $1558 \mathrm{r}$. [sic] tączyła też zasadę jawności z zasada szczegółowości, tzn. reguła, iż wpis $w$ księdze powinien dokładnie określać sumę wierzytelności zabezpieczonej oraz przedmiot zabezpieczenia. Chodziło o to, aby - jak stanowit przepis ustawy - „...ludzie nie zawodzili się pożyczając pieniądze super bona operata (na dobra obciążone), Rejestry nieruchomości..., s. 180.

Podobnego zabiegu dopatrywać się można przy fragmencie na s. 109.

D. Felcenloben: Od 1531 roku terminy te liczone byty od chwili wwiazania się nabywcy (wierzyciela) w posiadanie majątku podlegającemu retraktowi (wykup), tj. prawu bliższości wynikajacemu z pokrewieństwa, na podstawie którego pragnacy skorzystać z tego uprawnienia zobowiązany byl, w przypadku alienacji tych gruntów, zwrócić zastawnikowi sprawiedliwa cene (justa pecunia). 
przykłady. Na marginesie dodać można, że D. Felcenloben w swojej działalności na polu historii prawa nie stroni też od nagannej praktyki autoplagiatu. Omawiany artykuł ukazał się także - pod innym tytułem - na łamach „Rejenta” w 2013 r. ${ }^{101}$ Wcześniejszy - poświęcony powstaniu rejestrów gruntowych - opublikowano w „Czasopiśmie Prawno-Historycznym”, a następnie zamieszczony w dwóch częściach w „Przeglądzie Geodezyjnym”. W obu przypadkach o tych faktach czytelników już nie uprzedzono ${ }^{102}$.

VI. Artykuł D. Felcenlobena omówiony został zdecydowanie szerzej, niż na to zasługuje. Mimo to przedstawione powyżej uwagi z pewnością nie wyczerpują problemu braków warsztatowych, różnych błędów rzeczowych i wątpliwych tez, a jedynie obrazują jego wartość merytoryczną. Podstawowy błąd tkwi w samym założeniu, zrównującym dawne księgi sądowe z rejestrami gruntowymi. Tymczasem księgi nimi nie były, choć wśród rozlicznych funkcji pełniły także zbliżone do dzisiejszych rejestrów. Bodaj największą jeśli nie jedyną - zaletą artykułu jest możliwość wykorzystania go w celach dydaktycznych: stanowi on dobry materiał do wykazywania, jak nie można prowadzić badań historycznoprawnych. Do tak surowej oceny uprawniają: niesamodzielność wywodu, niezrozumienie tekstu przytaczanych źródeł i błędne do nich odesłania, brak znajomości literatury przedmiotu i wynikająca z niego bardzo duża liczba błędów rzeczowych, fatalny aparat naukowy. Jednocześnie pominięto podstawowe, wymagające zbadania problemy: funkcjonowanie zasad hipotecznych (praktyczne ograniczenia zasady jawności, istnienie zasady szczegółowości), czy też postępowanie egzekucyjne z zastawu hipotecznego.

Na zakończenie nasuwa się jeszcze jedna refleksja - tylko pośrednio związana z omawianym artykułem - dotycząca sposobu badania historii prawa. Szkoła komparatystyczna umniejsza potrzebę analitycznej pracy na podstawie źródła historycznego oraz neguje potrzebę powstawania monograficznych opracowań niezwiązanych z dzisiejszym prawem. Wskazać jednak można deficyty takiego rozumowania. Po pierwsze: ujęcia syntetyczne i opierające się na nich wnioski porównawcze w czasie i przestrzeni daje się przeprowadzić tylko w sytuacji solidnego opracowania monograficznego porównywanej instytucji. Takie zaś częstokroć jest możliwe dopiero po setkach godzin spę-

K. Dunin: Termin wykupu byt taki sam jaki zwyczaj wymagat dla przedawnienia, t. j. trzyletni; od r. 1531 liczono go dopiero od chwili wwiazania nowonabywcy do majątku ulegajacemu retraktowi. [...] Pragnacy skorzystać z prawa bliższości obowiązany byl zwrócić nabywcy lub zastawnikowi sprawiedliwa cene (justa pecunia), op. cit., s. 157-158.

${ }^{101}$ D. Felcenloben, Ksztaltowanie się instytucji ksiag gruntowych od czasów najdawniejszych do pierwszego rozbioru Polski, „Rejent”, 2013, nr 8, s. 131-149.

102 Por. idem, Przyczynek do powstania...; idem, Przyczynek do powstania rejestrów gruntowych - od czasów najdawniejszych do średniowiecza w Europie, cz. I, „Przegląd Geodezyjny”, nr 12/2012, s. 4-8; cz. II, „Przegląd Geodezyjny”, nr 1/2013, s. 3-6. 
dzonych nad dokumentami archiwalnymi. W innym wypadku pojawiać się mogą tezy opierające się na błędnych przesłankach. Uwaga ta jest szczególnie ważna dla słabo zbadanego staropolskiego prawa sądowego. Po drugie: skoro uznamy, że metoda historyczna nie jest potrzebna do badania historii prawa, musi ustąpić w cień na rzecz „użyteczności” podejmowanych badań i tematów dla dzisiejszego prawa, to stąd już tylko krok do wniosku, iż właściwie powinni prowadzić je teoretycy i praktycy prawa, najlepiej zorientowani w potrzebach swoich dyscyplin. Ujęcia porównawcze w zakresie historii prawa są jednakowoż niezmiernie trudne, wymagające solidnego warsztatu zarówno prawniczego, jak i historycznego. Omawiany artykuł - jakkolwiek niezwiązany stricte $\mathrm{z}$ komparatystyczną historią prawa - pokazuje jednak, jakie mogą być konsekwencje zbyt powierzchownie prowadzonych badań, opartych wyłącznie na prawoznawstwie i należy go traktować jako swoistą przestrogę przed lekceważeniem metody historycznej. 
